\title{
DISCLAIMER
}

This report was prepared as an account of work sponsored by an agency of the United States
Government. Neither the United States Government nor any agency thereof, nor any of the bility for the accuracy, completeness, or implied, or assumes any legal liability or responsiprocess disclosed, or represpletens, or usefulness of any information, apparatus, or responsience herein to any specific comts that its use would not infringe privately owned, product, or manufacturer, or otherwic commercial product, process, or service by trade naghts. Refermendation, or favoring does not necessarily constitute or ice by trade name, trademark, and opinion United States of authors expressed herein do not necessarily any agency thereof. The views United States Government or any agency thereof.

\section{DE89 014791}

PERFORMANCE MONITORING REPORT

FOR THE NIAGARA FALLS STORAGE SITE

WASTE CONTAINMENT STRUCTURE

CALENDAR YEAR 1987 AND JANUARY - JUNE OF 1988

JANUARY 1989

Prepared for

UNITED STATES DEPARTMENT OF ENERGY

OAK RIDGE OPERATIONS OFFICE

Under Contract No. DE-AC05-810R20722

By

J.A. Blanke, R.T. Johnson, and W.F. Stanley

Bechtel National. Inc.

Oak Ridge, Tennessee

Bechtel Job No. 14501 


\section{DISCLAIMER}

This report was prepared as an account of work sponsored by an agency of the United States Government. Neither the United States Government nor any agency Thereof, nor any of their employees, makes any warranty, express or implied, or assumes any legal liability or responsibility for the accuracy, completeness, or usefulness of any information, apparatus, product, or process disclosed, or represents that its use would not infringe privately owned rights. Reference herein to any specific commercial product, process, or service by trade name, trademark, manufacturer, or otherwise does not necessarily constitute or imply its endorsement, recommendation, or favoring by the United States Government or any agency thereof. The views and opinions of authors expressed herein do not necessarily state or reflect those of the United States Government or any agency thereof. 


\section{DISCLAIMER}

Portions of this document may be illegible in electronic image products. Images are produced from the best available original document. 
Abbreviations $\quad$ v

1.0 Introduction 1

1.1 Location and Description 2

1.2 Objective 6

2.0 Summary of Performance Monitoring Program 7

3.0 Performance Monitoring Data 10

3.1 Surface Monitoring 10

3.1.1 Aerial Photography 10

3.1 .2 Topographic Survey 10

3.1 .3 Walkover Survey 15

3.2 Subsurface Monitoring 20

3.3 Environmental Monitoring 23

3.3.1 Radon 23

3.3.2 External Gamma Radiation Levels 23

3.3.3 Groundwater Monitoring $\quad 24$

4.0 Comparison with Previous Data 32

5.0 Actions Required 33

References

Appendix A - Sumary of Vibrating Wire Pressure
Transducer Data for Calendar Year 1987 and January-June 1988

Appendix B - Comparison of Vibrating wire Pressure

Transducer Data to Pneumatic Pressure

Transducer Data - July 1987 to June $1988 \quad$ B-1 


\section{LIST OF FIGURES}

Figure Title

Page

1-1 The Regional setting of the NFSS

3

2-2

Site Plan of the NFSS

4

$1-3$

Cross section of the NFSS waste Containment

5 structure

2-1

Locations of VWPTs and PPTs on the waste

Containment structure

3-1 Aerial Mapping of the NFss waste Containment structure

3-2A Aerial View of the NFSS Waste Containment Structure - October 1987

3-2B Aerial View of the NFSS Waste Containment

3-3

Structure - October 1986

Survey Grid for the NFSS waste Containment Structure

Areas Requiring Maintenance Actions - WCS

Location of NFSS Groundwater Monitoring wells in the vicinity of the waste Containment structure

Surface water, Groundwater, and sediment Sampling Locations at the NFSS 
Table Title

Page

3-1 Elevations in Feet (MSL) at Grid Intersections. NFSS Waste Containment Structure - May 1987

3-2 Elevations in Feet (MSL) at Grid Intersections. NFSS Waste Containment structure - April 1988

3-3 Sumary of Subsurface Monitoring Instruments 1987

3-4 Concentrations of Uranium in NFSS water Samples - December 1986 to April 1988

3-5 Concentrations of Radium-226 in NFSS Water Samples - December 1986 to April 1988

3-6 Concentrations of Uranium in NFSS Containment Monitoring Wells - April 1987 to April 1988

3-7 Concentrations of Radium-226 in NFSS Containment Monitoring Wells - April 1987 to April 1988

B-1 Comparison of VWPT Data to PPT Data - July 1987 to June 1988 


\section{ABBREVIATIONS}

cm

centimeter

ft

foot

FY

fiscal year

ha

in.

hectare

km

inch

mi

kilometer

mile

ms 1

mean sea level

$\mu \mathrm{Ci} / \mathrm{ml}$

microcuries per milliliter

$\mathrm{pCi} / \mathrm{I}$

PPT

VWPT

wCS

picocuries per liter

pneumatic pressure transducer

vibrating wire pressure

transducer

Waste Containment structure 


\subsection{INTRODUCTION}

A performance monitoring program has been developed for the Niagara Falls storage site (NFSS) Waste containment structure (WCS). The WCS contains soils contaminated with residual radioactive materials, rubble, and radioactive residues removed from various areas of the NFSS and vicinity properties during remedial action conducted by the Department of Energy (DOE) from 1982 through 1986. The NFSS is a part of the DOE Surplus Facilities Management Program (SFMP). The design and construction of the containment structure have been previously documented (Ref. 1). The closure and post-closure activities have also been previously documented (Ref. 2).

The purpose of the performance monitoring program is to verify that the wCs main engineering elements are functioning to minimize infiltration of rainfall; prevent pollution of groundwater; preclude formation of leachate; and prevent radon emanation. This report presents the findings of performance monitoring conducted at the wCS during calendar year 1987, and January through June of 1988. The data received during the initial performance monitoring period in 1986 (Ref. 3) established a baseline for interpretation contained in this report. The period covered by this report has been expanded to include 6 months in 1988 because the impact of the winter is most evident in the spring growing season.

The performance monitoring program is distinct from the environmental monitoring program conducted at the NFss, and will continue for a shorter time. The performance monitoring program will continue for a minimum of 5 years (FY 1987-1991), but may be maintained for a longer period depending on the results observed. To evaluate accurately the effectiveness of the containment facility. the data from both the performance monitoring program and from the broader environmental monitoring program must be assessed. The environmental monitoring program monitors radon concentrations in air; radium, uranium, and heavy metals concentrations in surface water, groundwater, and sediment; and external gamma radiation levels. It includes data from both the monitoring wells on- and 
off-site and the 36 wells added to the monitoring list since 1986 . Complete results of the environmental monitoring program are published annually in a separate report (Ref. 4). Summary information from that report is included in this document in subsection 3.3 .

This report includes a summary of performance monitoring results for 1987 and 6 months of 1988, with data for surface, subsurface, and environmental monitoring; conclusions based on walkover surveys; comparisons with previous data; and actions required. The vibrating wire pressure transducer (VWPT) pore water pressure readings have been expressed as hydraulic head and are plotted in Appendix $A$ for 1987 and for the first half of 1988 . Due to technical difficulties (noted in subsection 3.2), data for entire period could not be collected. The pneumantic pressure transducer (PPT) pore water pressure readings have been converted to hydraulic head and are presented in Appendix B. Appendix B compares the PPT data to the VWPT data: The comparison shows how failure of the VWPTs was detected.

\subsection{LOCATION AND DESCRIPTION}

The NFSS is a DOE surplus facility located in northwestern New York within the Township of Lewiston (Niagara County). The site is located in a generally rural setting approximately $4 \mathrm{mi}(6.4 \mathrm{~km})$ south of Lake ontario and $10 \mathrm{mi}(16 \mathrm{~km})$ north of the City of Niagara Falls. The NFSS and its regional setting are shown in Figure $1-1$. Figure $1-2$ is a site plan of the NFSS featuring the wCS.

The wcs occupies 10 acres (4 ha) of the 191-acre (77.4-ha) NFSS. As shown in Figure 1-3, the wCs outer perimeter is formed by a dike and cutoff wall. each constructed of compacted clay and incorporated into the finished structure. The cutoff wall extends a minimum of 18 in. (45 cm) into an underlying gray clay unit. The gray clay unit and the cutoff wall/dike serve as adsorption barriers to vertical and horizontal migration of contaminants from the structure. 


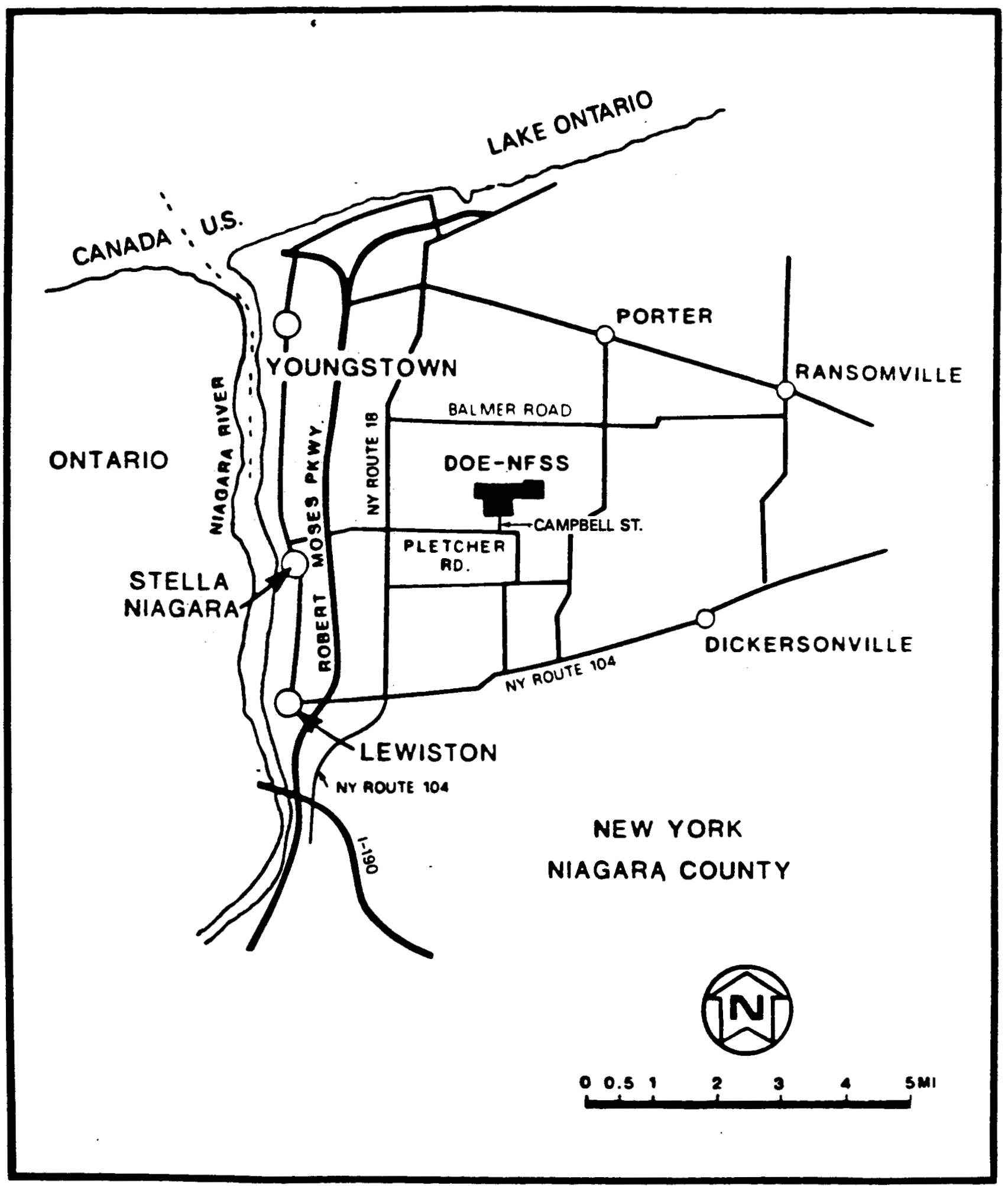

FIGURE 1-1 THE REGIONAL SETTING OF THE NFSS 



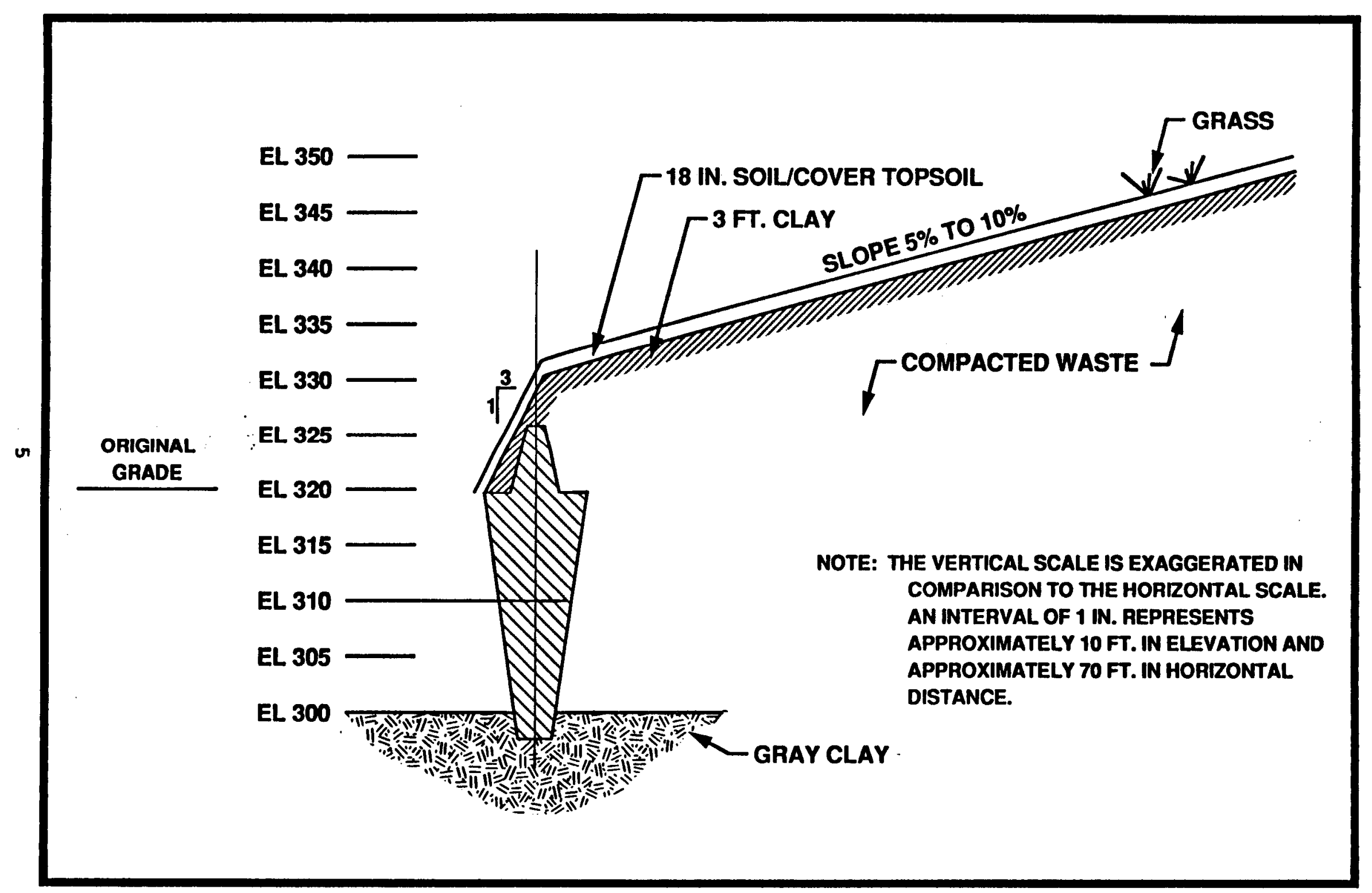

FIGURE 1-3 CROSS SECTION OF THE NFSS WASTE CONTAINMENT STRUCTURE 
An engineered, compacted clay cover is placed immediately over the wastes and extends beyond the perimeter dike, completely enclosing the containment structure. This clay cover is the principal barrier against moisture intrusion and radon emanation. The clay layer is covered with a surface layer of loosely compacted, 18-in.-thick soilcover and topsoil. This surface layer forms a protective blanket to maintain moisture and prevent drying that could result in the formation of tension cracks within the clay layer and to reduce the effects of frost. It also provides a base for shallow-rooted grass. The clay layer, soil cover, and topsoil comprise the short-term closure system for the wCS.

\subsection{OBJECTIVE}

The primary objective of the performance monitoring program is early detection of trends that could indicate weaknesses developing in the containment structure. The monitoring system serves as the basis for a preventive maintenance program, allowing corrective action to be taken before the integrity of the structure is compromised. Consequently, subsurface as well as surface monitoring techniques are used. Possible indications of structural distress include

- Differential settlement of the wastes

- Desiccation cracking of the clay cover

- Horizontal displacement

- Deep surface erosion

- Animal burrowing

- Deep-rooted vegetation

- Rapid rise of the potentiometric (saturated) surface inside the containment structure

- Residual reduction in soil density due to frost heave 


\subsection{SUMMARY OF PERFORMANCE MONITORING PROGRAM}

The performance monitoring program at the NFSS was initiated in November 1986 to monitor the surface and subsurface conditions of the wCS. Surface techniques were used to check waste placement, the various layers of the containment facility cover, and surface drainage. Subsurface instrumentation monitors the performance of the clay cap. the gray clay unit, and the cutoff wall/dike.

Surface monitoring activities include topographic surveys, walkover surveys, and aerial photography completed at least annually. Initial aerial photographs were taken in early June 1987 to provide the reguired baseline photographic data. This aerial mapping provided a reference for detection of changes in the surface contours of the wCS to supplement the information provided by the topographic and walkover surveys.

The topographic and walkover surveys were initially performed in the fall of 1986 following closure of the wCS. These activities established the baseline for ensuing annual performance monitoring surveys. Data obtained represented the initial condition of the wcs and provided the basis for determining whether any additional maintenance actions were required. As a result of the initial and subsequent walkovers, several actions have been taken to maintain the required performance results. These actions include adding topsoil to low areas, seeding and fertilizing, placing erosion control netting, and repairing well casings. The results of the surface monitoring are discussed in subsection 3.1 , and the actions required are discussed in section 5.0 .

Subsurface monitoring instrumentation includes VWPTs to monitor pore water pressure and a secondary system of PPTs to provide a check on the operation of the VWPTs. The locations of these devices are shown in Figure 2-1. The PPTs were installed adjacent to three of the VWPTs. The PPTs had only one reading in 1986, which was the initial reading in November after installation. Monthly readings 


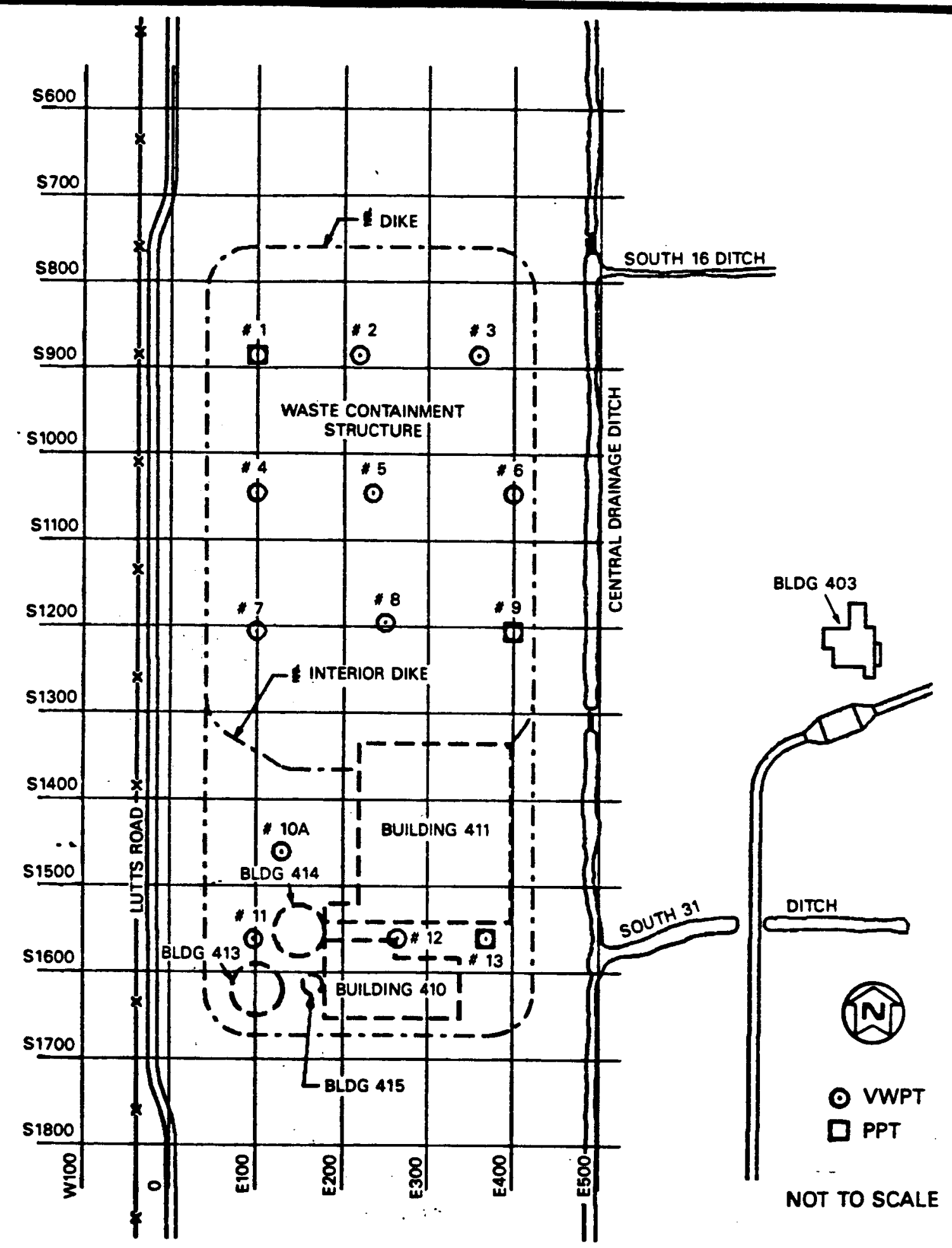

FIGURE 2-1 LOCATIONS OF VWPTS AND PPTS ON THE WASTE CONTAINMENT STRUCTURE 
began in July 1987. The frequency of readings will be adjusted based on results of subsequent years' operation.

The VWPTs record readings automatically each day, and data are examined on a regular basis to detect any early indication of water accumulating inside the wCS. A summary of the data from the VWPTs is presented in Appendix $A$. There are no valid VWPT data from July 1987 to February 1988. Lightning damaged the power supply, and repairs had to be made to the read-out instrumentation. This problem is now corrected. The secondary system, the PPTs, showed that the VWPTs were providing erroneous readings. The comparison of PPT data to VWPT data is presented in Appendix $B$.

Walkover surveys and data collected from monitoring wells and VWPTs confirm that the wCs is functioning as predicted and providing isolation for the waste. 


\subsection{PERFORMANCE MONITORING DATA}

This section provides the results of the performance monitoring and a summary of the results of the environmental monitoring at the NFSS for calendar year 1987 and January through June of 1988. The specific details of the hydraulic head monitoring results for this period are provided in Appendix $A$ and Appendix $B$. Complete environmental monitoring information is provided in Reference 4.

\subsection{SURFACE MONITORING}

\subsubsection{Aerial Photography}

The most recent contour mapping of the wCs surface was performed in October 1987 (see Figure 3-1). The 1986 mapping showed depressions in the northwest section of the wCS where the trenches for the transducer cables had been dug; however, these depressions did not appear in the 1987 survey. The 1987 survey showed a stable cap with no appreciable change in elevations or configuration.

The latest aerial view of the wCS (Figure $3-2 \mathrm{~A}$ ) was taken in October 1987. When compared with the October 1986 (Figure 3-2B) aerial view, it can be clearly seen that the formerly bare areas in the middle and at the south end of the wCs now have well established turf. The water holding ponds shown in the 1986 photograph have been filled in and, therefore, are not in the 1987 view. The 1987 photograph documents corrective actions taken as a result of the performance monitoring program.

\subsubsection{Topographic survey}

Topographic surveys of the cap surface were performed in 1987 and 1988 on the predetermined grid shown in Figure 3-3. The grid layout utilized 100-ft spacing: north/south grid lines were designated with alphabetic characters and east/west grid lines were designated with numeric characters. At each grid intersection, 2- by 2- by 8-in. wooden stakes were driven flush with the surface of the topsoil. 


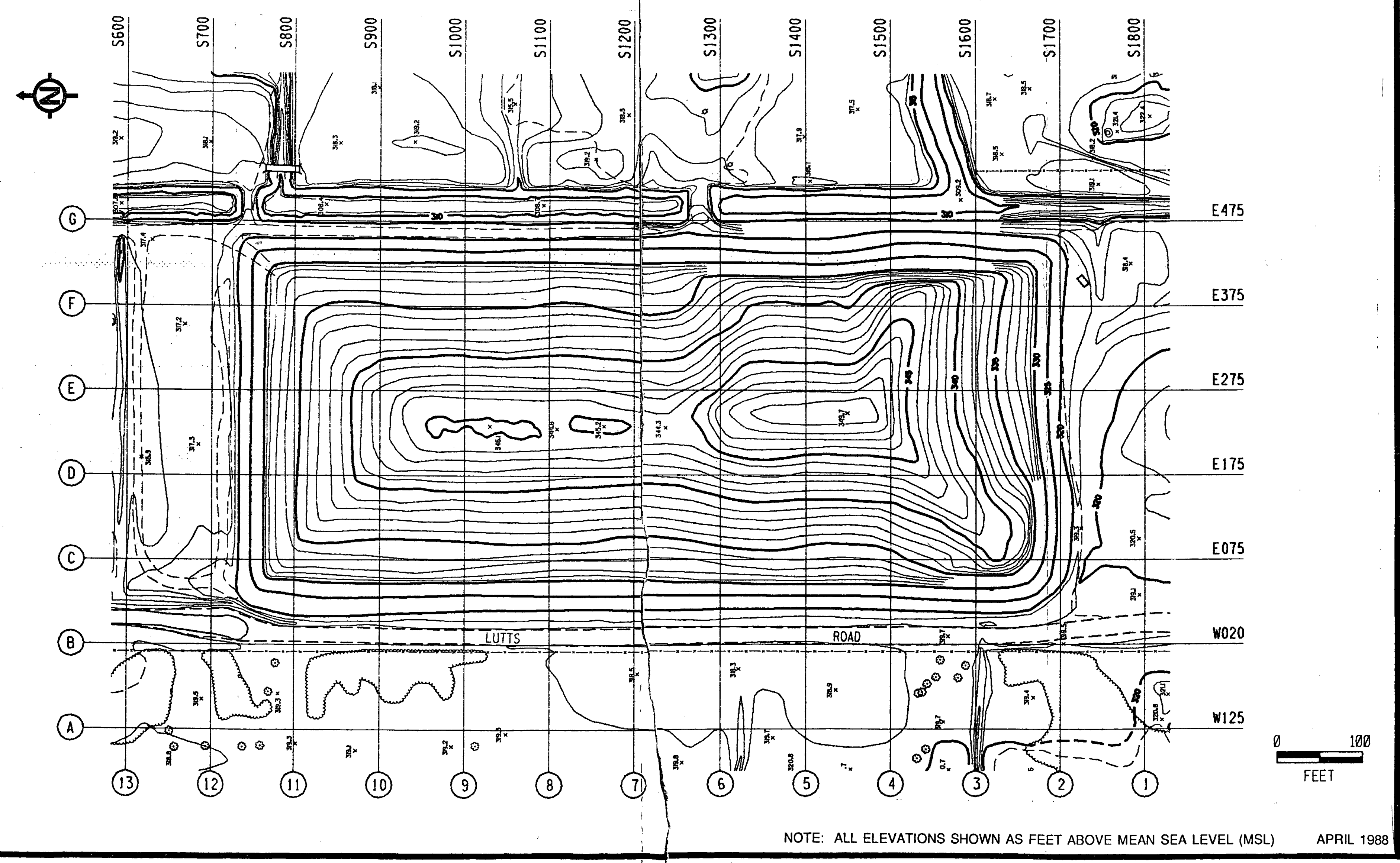

FIGURE 3-1 AERIAL MAPPING OF THE NIFSS WASTE CONTAINMENT STRUCTURE GRB: [ 42,25$] 191 F 99011.06 \mathrm{~N}$ 
$+$
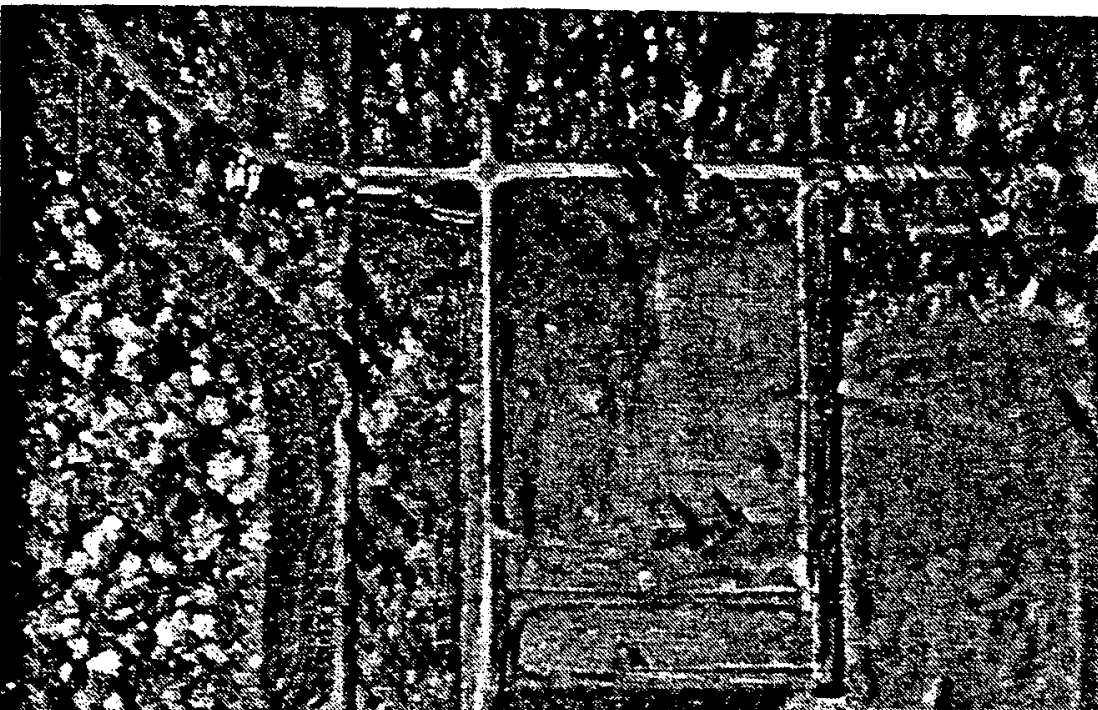

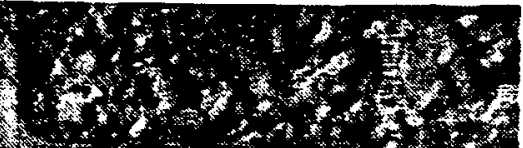
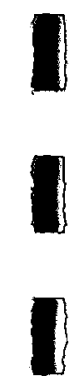

$+x+4$
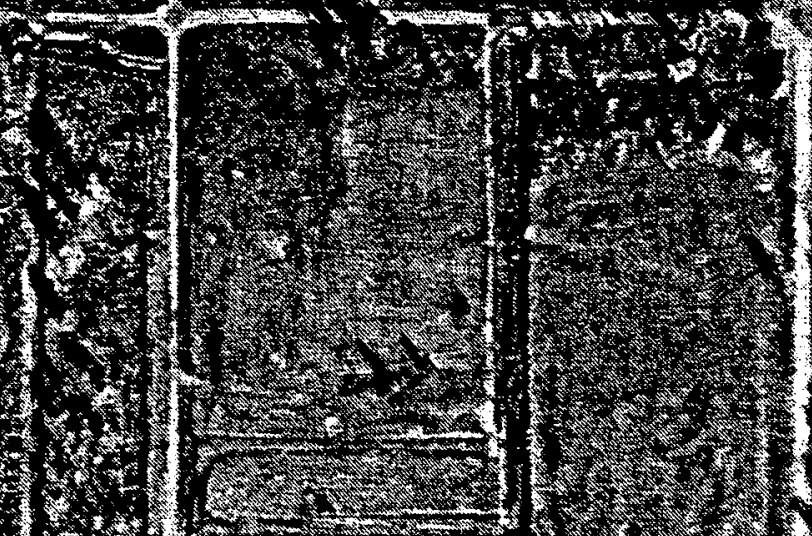

$128+3 \times 4$

$1+2+21$

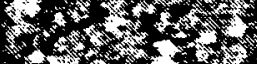

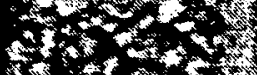

$+1+8 \times$

H.

$1+2+2$

$13,2, y, y, 2$

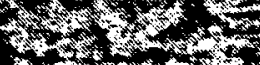

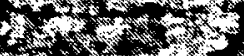

$+2 x+3$

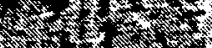

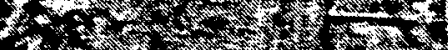

$8 x+2,3 y+3 y$

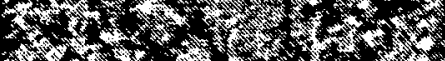

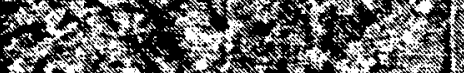

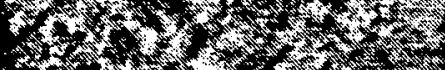

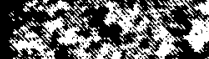

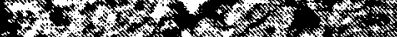

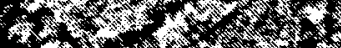

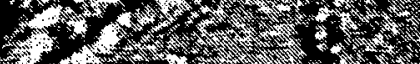

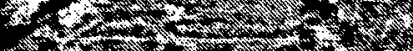

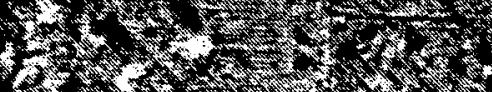
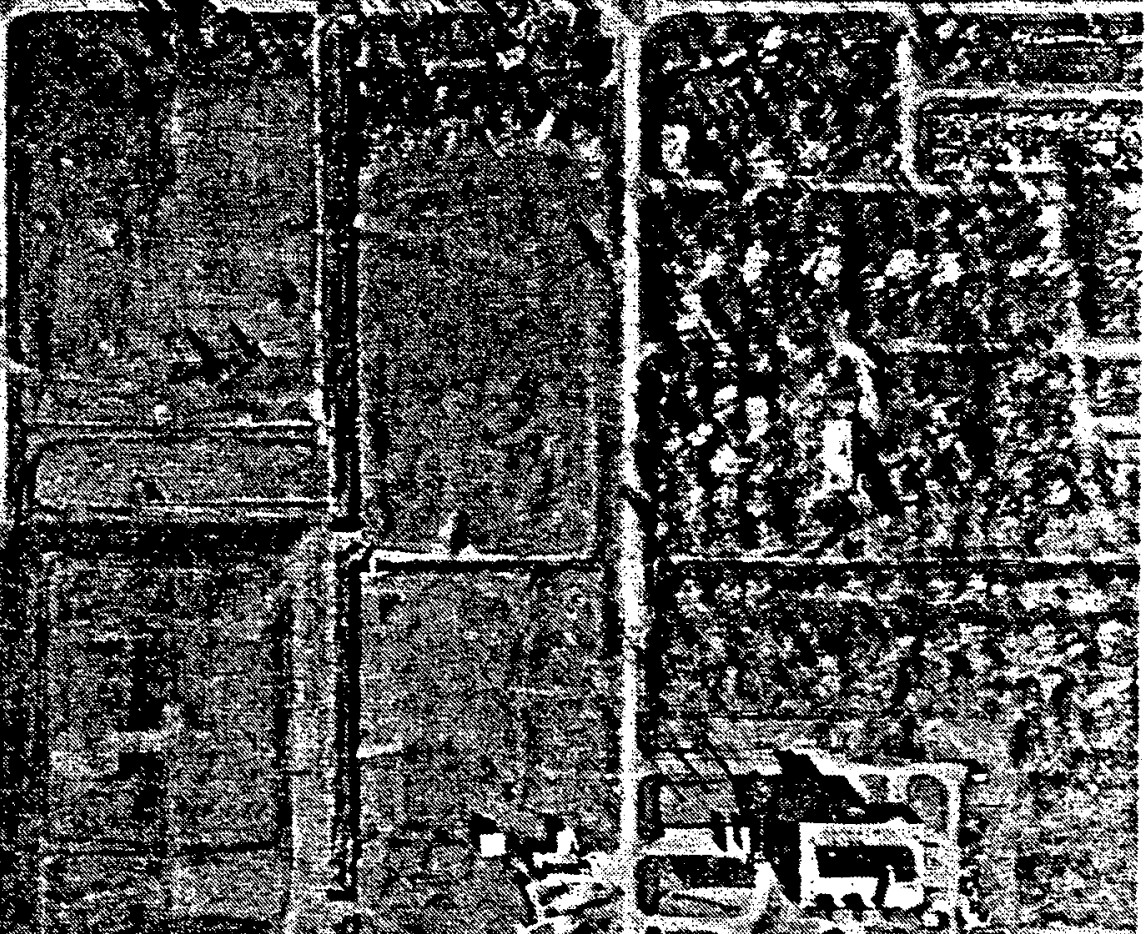

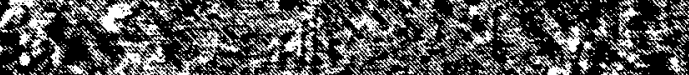

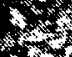

(N) pobers

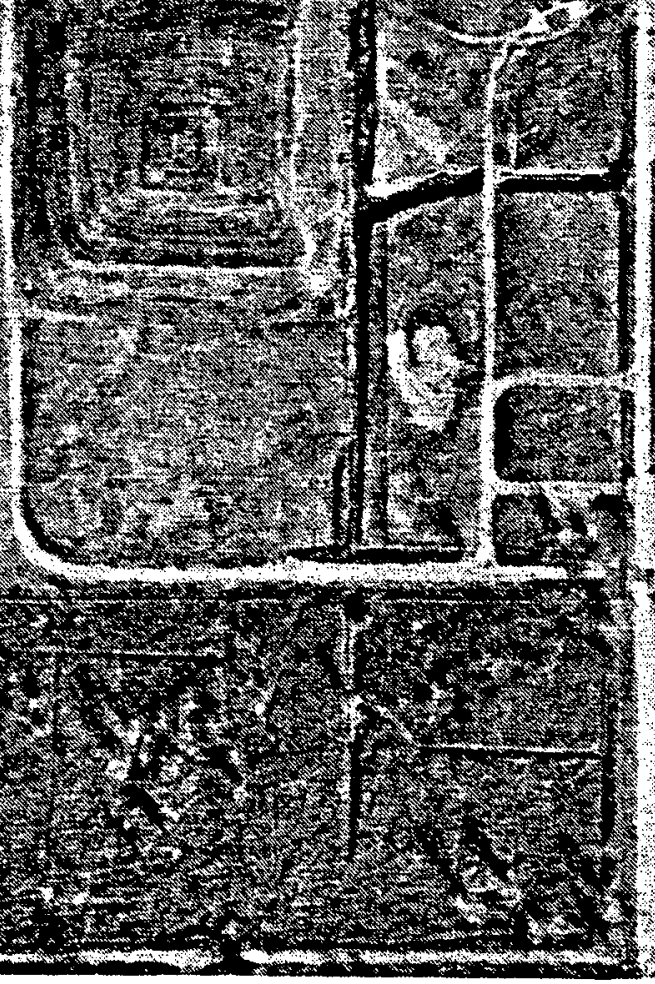

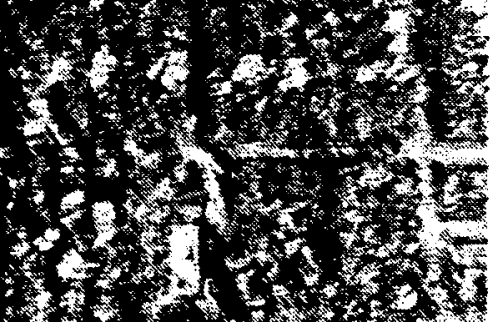
$x+3,2+234$

$x+3,+2,3+2$

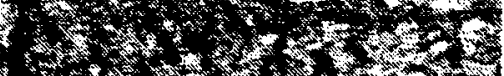

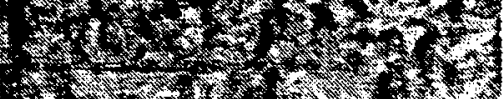

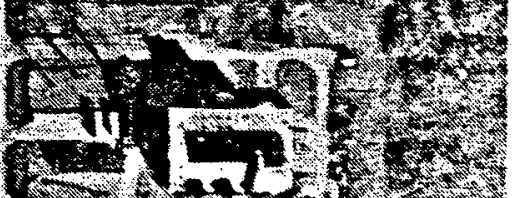
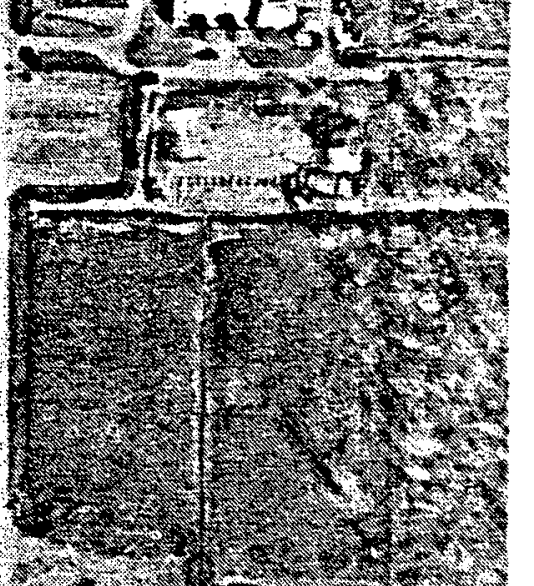

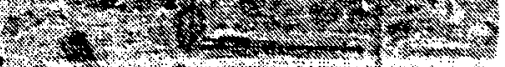

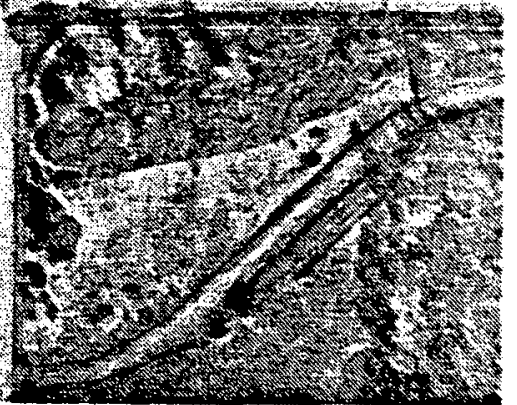

FIGURE 3-2A AERIAL VIEW OF THE NFSS WASTE CONTAINMENT STRUCTURE — OCTOBER 1987 


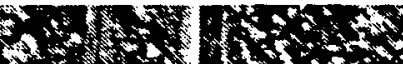

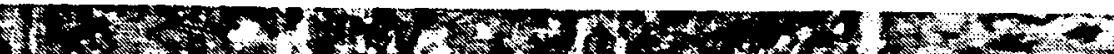

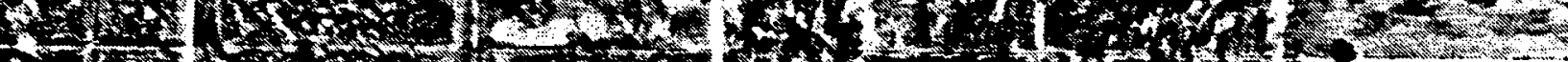

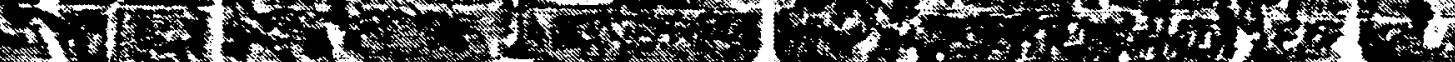

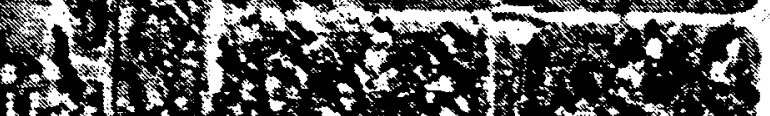

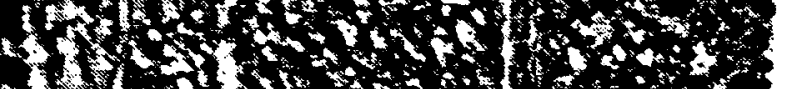

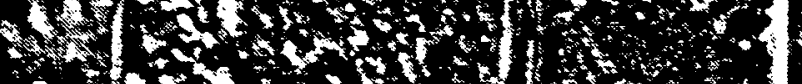

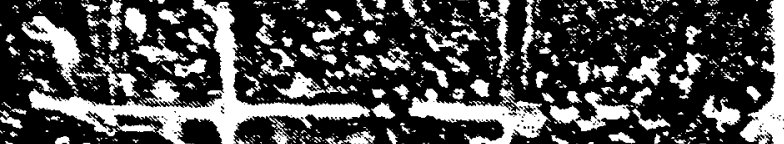

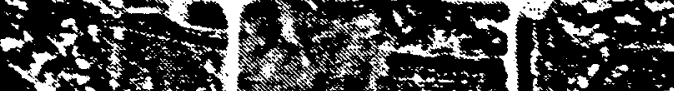

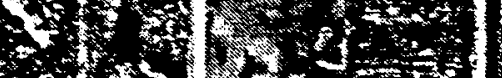

$6+x-1$

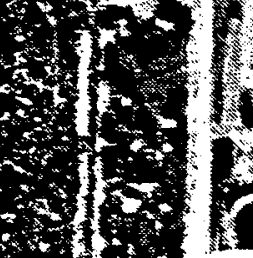

46

$\frac{1}{4}$

18

$+3$

Bate

$\rightarrow+1$

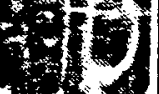

$+1$

.
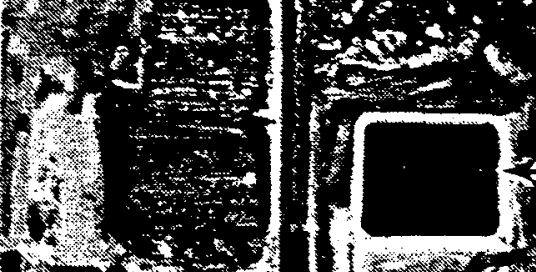

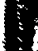

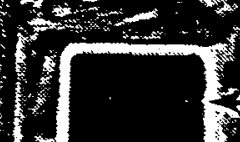

$8+$

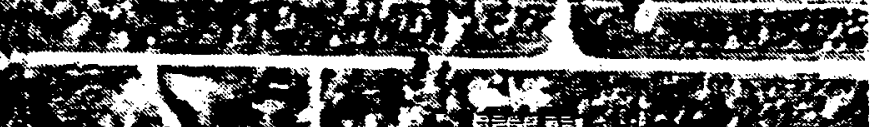

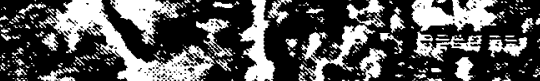

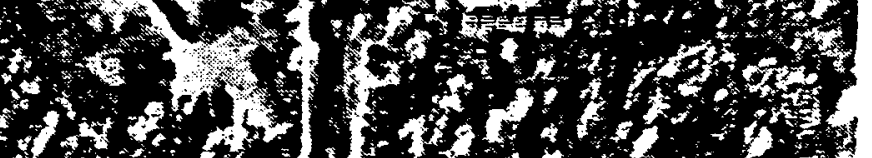

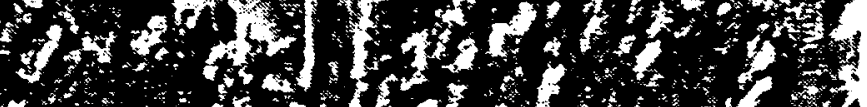

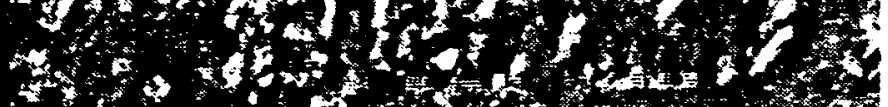

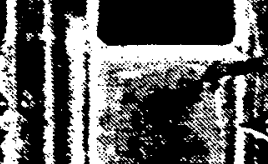

2.
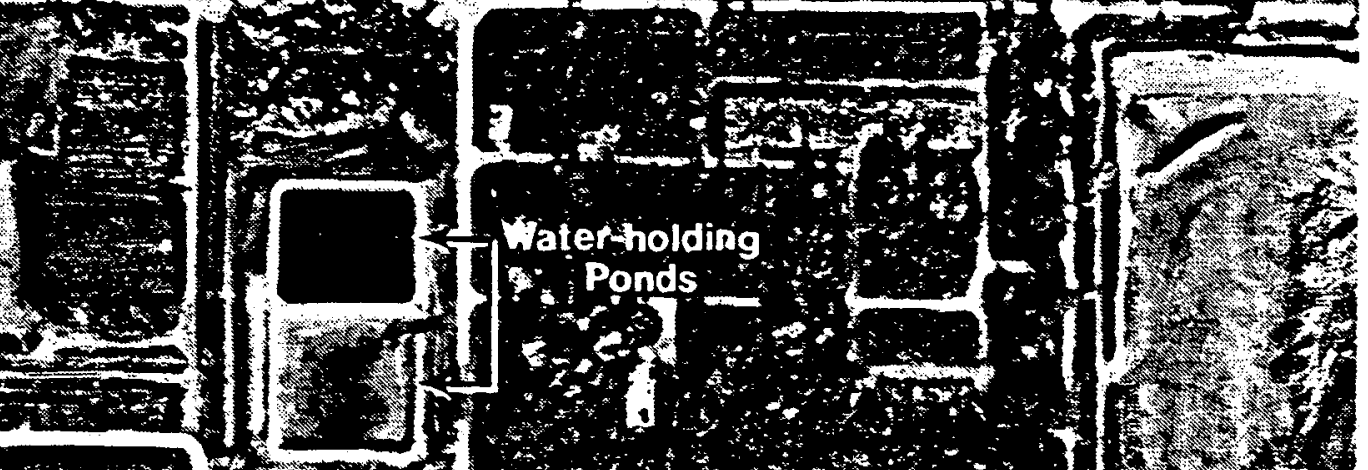

Thaterholding
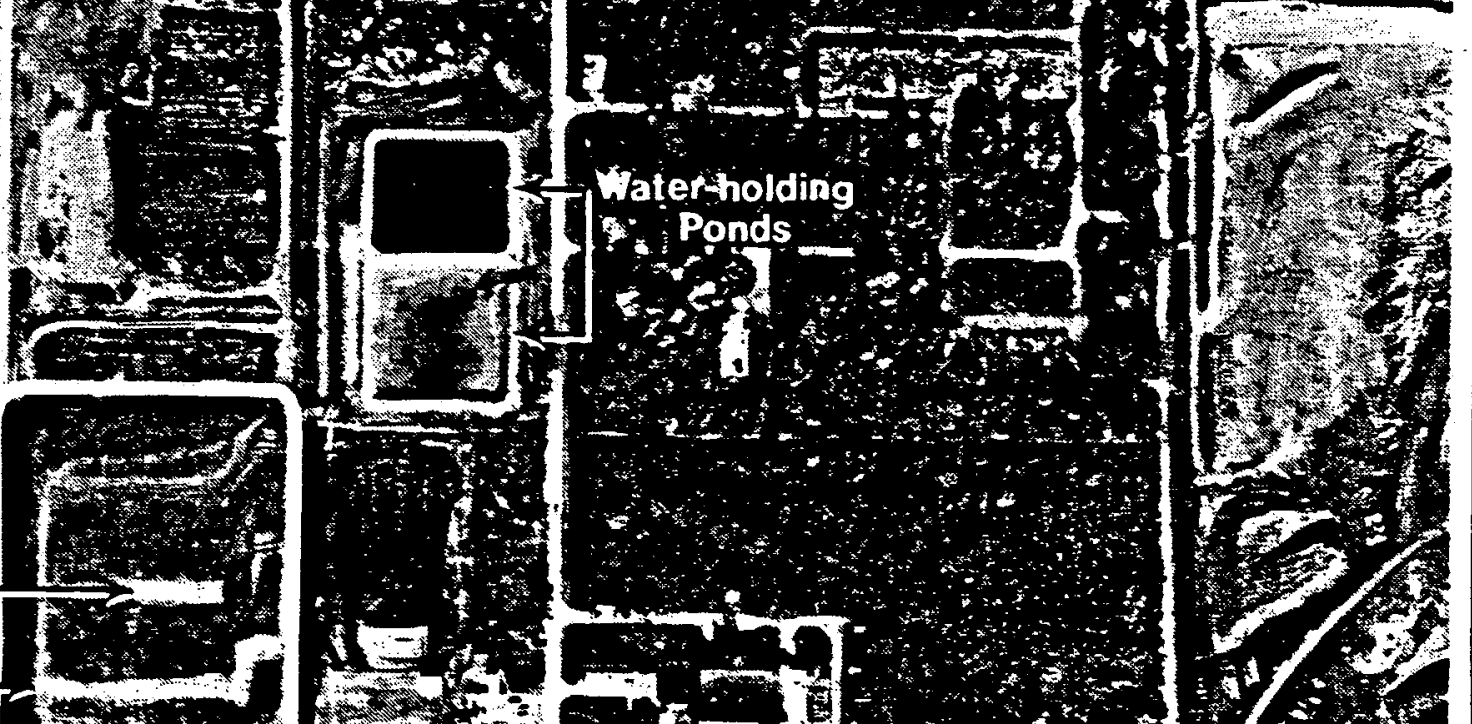

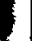

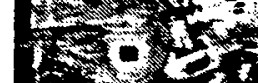

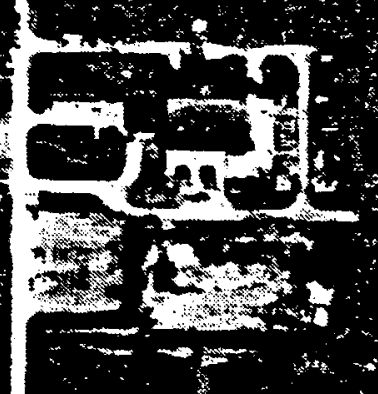

I

1

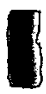
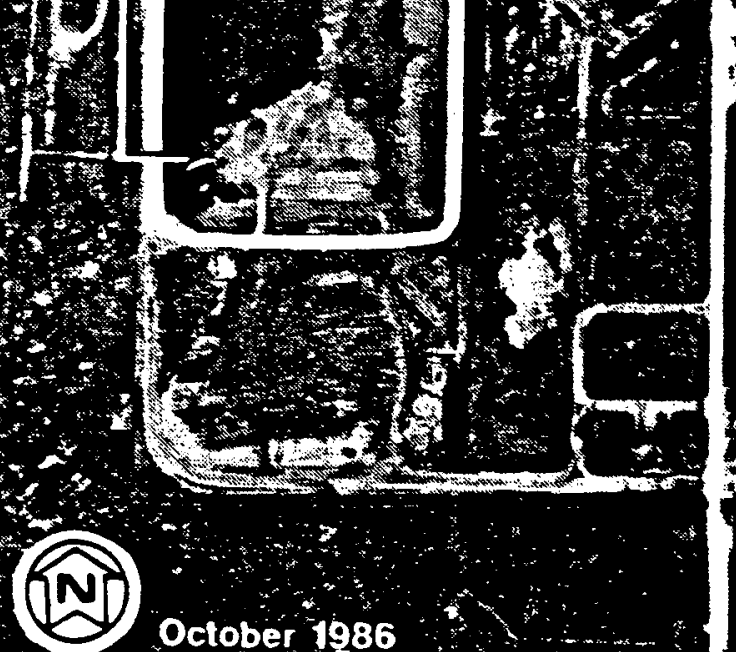

$8+20$

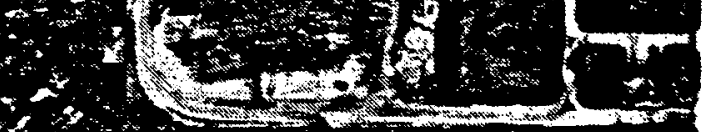

October 1986

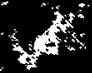

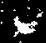

\section{FIGURE 3-2B AERIAL VIEW OF THE NFSS WASTE CONTAINMENT STRUCTURE - OCTOBER 1986}




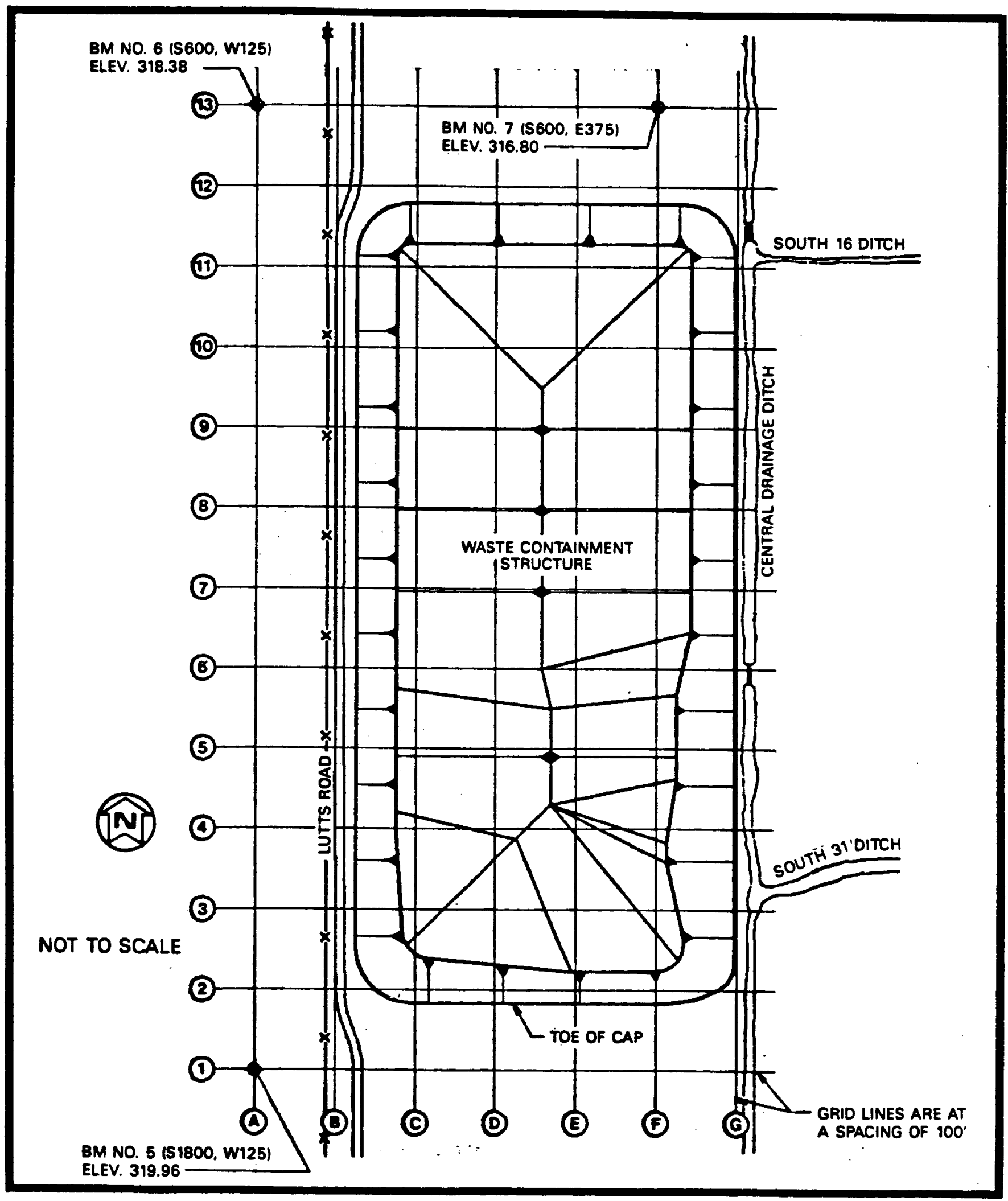

FIGURE 3-3 SURVEY GRID FOR THE NFSS WASTE CONTAINMENT STRUCTURE 
and elevations were measured. The elevations and changes obtained at these grid intersections are reported in Tables 3-1 and 3-2. The stakes were left in place for future elevation comparisons.

Permanent benchmarks were installed at three grid intersections: S1800, Wl25; s600, Wl25; and s600, E375. The benchmarks are tied to the New York state Plane Coordinate System; the corresponding coordinates on this system are N1,170,797.56, E392,146.12; N1.171.997.47,E392.146.32: and N1.171,997.39,E392,646.28. Each benchmark is a permanent concrete monument with a brass designation marker.

Tables 3-1 and 3-2 show that there have been some localized elevation changes in the wCS. There are no patterns of change and no significant deviations, except for the -0.5-ft (station 12-E). -0.8-ft (Station 1-E), +l.0-ft (station 1l-C), and -l.1-ft (station 12-F) changes. Of these points, only 12-F shows any significant change when the 1987 and 1988 surveys are compared. This point lies in a drainage ditch and the activity of drainage may have affected this point. Of these four stations, only station ll-c is located on the wCS. Review of station ll-c during the spring 1987 walkover showed no apparent differential settlement. The +1.0-ft deviation was judged to be due to a survey ercor based on field examination and lack of surface evidence of distress. The area will be given special consideration at the next survey.

\subsubsection{Walkover survey}

\section{Calendar Year 1986}

The initial walkover survey was performed on November 17 and 18. 1986, by a team of engineering, geotechnical, construction, and site operations personnel. The team evaluated the cap condition for settlement or movement, cracking, undesired plant growth, or other undesirable conditions. The walkover survey covered the wCs and the 
TABLE 3-1

ELEVATIONS IN FEET (MSL) AT GRID INTERSECTIONS, NFSS WASTE CONTAINAENT STRUCTURE ${ }^{a}$

MAY 1987

E/W Grid Linesb

\begin{tabular}{rr} 
& North/South Grid Lines \\
\hline C (E075) & D (E175)
\end{tabular}

\section{(2)}

D (E175) E (E275)

$\begin{array}{lllllll}12(s 700) & 318.1[-0.1]^{c} & 317.1[-0.1]^{c} & 317.1[-0.1]^{c} & 317.1[-0.1]^{c} \\ 11(s 800) & 333.2[+1.0] & 334.6[-0.1] & 334.4[-0.1] & 333.5[0.0] \\ 10(s 900) & 333.9[0.0] & 341.2[0.0] & 341.7[0.0] & 334.6[0.0] \\ 9(s 1000) & 333.6[0.0] & 341.7[-0.1] & 343.0[-0.1] & 334.5[0.0] \\ 8(s 1100) & 333.0[+0.1] & 341.5[-0.1] & 342.5[0.0] & 334.9[0.0] \\ 7(s 1200) & 333.0[0.0] & 341.2[0.0] & 342.3[0.0] & 335.0[0.0] \\ 6(s 1300) & 333.6[0.0] & 342.5[+0.1] & 344.8[+0.1] & 337.5[0.0] \\ 5(s 1400) & 333.7[0.0] & 343.1[-0.1] & 347.2[-0.2] & 339.5[-0.1] \\ 4(s 1500) & 334.4[-0.1] & 343.1[-0.1] & 347.0[-0.1] & 343.3[0.0] \\ 3(s 1600) & 338.7[-0.1] & 339.8[0.0] & 337.5[0.0] & 337.8[0.0] \\ 2(S 1700) & 323.1[0.0] & 321.2[0.0] & 319.7[-0.2] & 320.4[-0.1] \\ 1(s 1800) & 320.1[-0.1] & 320.7[-0.1] & 320.7[-0.7] & 317.6[0.0]\end{array}$

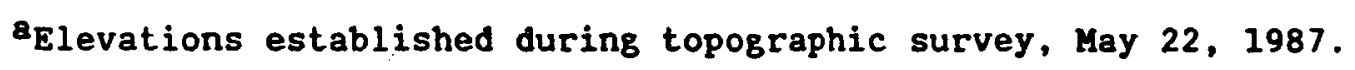

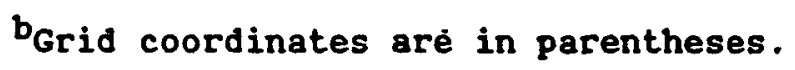

Changes in elevation from the 1986 survey (reported in the Performance Monitoring Report for the Niagara Falls Storage Site, DOE/OR/20722-159, July 1987) are in brackets. 
TABLE 3-2

ELEVATIONS IN FEET (MSL) AT GRID INTERSECTIONS, NFSS

WASTE CONTAIMHENT STRUCTURE

APRIL 1988

\begin{tabular}{|c|c|c|c|c|c|}
\hline \multirow{2}{*}{$E / W$} & \multirow[b]{2}{*}{ Linesb } & \multicolumn{4}{|c|}{ North/South Grid Lines b } \\
\hline & & C (E075) & D (E175) & $E(E 275)$ & F (E375) \\
\hline 12 & $(5700)$ & $318.2[0.0]^{c}$ & $317.1[-0.1]^{c}$ & $316.6[-0.5]^{c}$ & $316.1[-1.1]^{c}$ \\
\hline 11 & $(5800)$ & $333.2[+1.0]$ & $334.7[0.0]$ & $334.5 \quad[0.0]$ & $333.6[-0.1]$ \\
\hline 10 & $(s 900)$ & $333.9[0.0]$ & $341.2[0.0]$ & $341.7[0.0]$ & $334.7[0.0]$ \\
\hline 9 & $(S 1000)$ & $333.6 \cdot[0.0]$ & $341.7[-0.1]$ & $342.9[-0.2]$ & $334.5[0.0]$ \\
\hline 8 & $(S 1100)$ & $333.1[0.0]$ & $341.4[0.0]$ & $342.5[0.0]$ & $334.8[0.1]$ \\
\hline 7 & $(S 1200)$ & $333.0[0.0]$ & $341.2[0.0]$ & $342.2[-0.1]$ & $334.9[-0.1]$ \\
\hline 6 & $(S 1300)$ & $333.6[0.0]$ & $342.5[+0.1]$ & $344.7[0.0]$ & $337.5 \quad[0.0]$ \\
\hline 5 & $(\$ 1400)$ & $333.7[0.0]$ & $343.1[-0.1]$ & $347.1[-0.3]$ & $339.5[-0.1]$ \\
\hline 4 & $(\$ 1500)$ & $334.5[0.0]$ & $343.1[-0.1]$ & $346.7[-0.4]$ & $343.2[-0.1]$ \\
\hline 3 & $(S 1600)$ & $338.8[0.0]$ & $339.7[-0.1]$ & $337.5 \quad[0.0]$ & $337.7[-0.1]$ \\
\hline 2 & $(S 1700)$ & $323.0[-0.1]$ & $321.2[-0.1]$ & $319.8[-0.1]$ & $320.3[-0.2]$ \\
\hline & $(S 1800)$ & $320.0[-0.2]$ & $320.8[0.0]$ & $320.6[-0.8]$ & $317.6[0.0]$ \\
\hline
\end{tabular}

aElevations established during topographic survey, April 28, 1988.

b Grid coordinates are in parentheses.

CChanges in elevation from the 1986 survey (reported in the Performance Monitoring Report for the Niagara Falls Storage Site, DOE/OR/20722-159, July 1987) are in brackets. 
surrounding area to about 100 ft from the toe of the cap. The survey was divided into four discrete areas of the wcs: the periphery side slopes; areas over former structures and foundations (Buildings 410,411,413,414, and 415): the general cap area; and the area surrounding the toe of the wCS.

To conduct the walkover survey, team members walked a preplanned route, based on the established grid, that ensured a complete. systematic inspection of the cap. The survey team observed some minor irregularities on the wCS, as listed below:
- Localized areas of sparse grass on the northern section
of the cap
- Tire tracks on the topsoil
- Locations of large clods on the cap surface
- Water infiltration into the geotechnical instrumentation manhole
- Poor drainage along the toe of the cap
- Isolated areas of erosion in the southern section of the cap

Photographs of these conditions are available in project files.

\section{Calendar Year 1987}

Walkovers were performed in May and October of 1987. Although the grass was better established than in 1986, localized areas were identified with undesirable plants, erosion, insufficient grass, and uneven grading. Settlement had occurred along trenches opened for installation of geotechnical instruments. sloughing was observed along the central Ditch and was especially evident on the west bank, nearest the wcs.

A number of actions were taken immediately following the May walkover. A turf management program was developed in late May and instituted in June. This program established pH levels for 
the soil, fertilization levels, herbicide application rates, types of grass for reseeding, and other actions to eliminate the turf problem areas. A mowing program was instituted in June. A reel-type irrigation system was purchased during July to irrigate the wCS during the dry season. Areas of settlement were backfilled to re-establish the original grade.

The October walkover confirmed that the actions taken had resolved many of the localized problems. Further sloughing was observed along the central Ditch and plans were made to repair the ditch in 1988 .

\section{Calendar Year 1988}

The spring 1988 walkover was completed in May of 1988. Turf conditions were greatly improved over those observed in 1986 and 1987. Grass on the north end of the wCs was well established. In areas at the south end that were reseeded as a result of the 1987 corrective actions, grass was becoming well established. It was raining on the day of the walkover, so drainage and the lack of pudding were evident. Sloughing along the central Ditch had continued and had advanced to within 6 ft of the southeast toe of the wCS at one point. Central Ditch sloughing will be corrected during the latter half of 1988 .

There were a number of localized areas where erosion control netting had been pulled up by mowing. There were small areas that needed reseeding and fertilizing. There was scarring on the north end (bare spot leading up the slope) of the wcs where the vehicle that relocated the irrigation guncart had been driven. The areas requiring maintenance are shown on Figure 3-4. There were no major problem areas. several new corrective actions were initiated because of the May walkover. Many maintenance practices established in 1987 continued. 
In July 1988, extensive polygonal desiccation cracking of the topsoil over the wCS was observed, especially where the grass was thin (Figure 3-4). This condition was initially visible in May 1987, but was exacerbated by the extremely hot, dry summer of 1988. Inspections by a field geologist after substantial rains disclosed no erosion associated with the cracking.

Observation of the cracking condition will continue. If the condition does not improve, actions will be taken to remedy the situation.

Actions to be taken in the future are discussed in section 5.0.

\subsection{SUBSURFACE MONITORING}

In Fall 1986, 13 VWPTs and 3 PPTs were installed inside the wCs, as shown in Figure 2-1. The three PPTs were installed at the same elevation and in the same boreholes as VWPTs 1, 9, and 13. The PPTs provide a means for checking the operation of the VWPTs. The instrument number, grid location, recorder channel, ground surface elevation, and instrument elevation are summarized in Table 3-3. VWPT readings were initiated on November 4,1986 .

The data from the VWPTs have been converted to hydraulic head and are plotted in Appendix $A$. The plots for instrument locations $2,5,8$, and 9 appear to have equalized. The plots for instrument locations $1,3,4,6,7,10,11,12$, and 13 each show a slight downward trend at the end of the period monitored. It is anticipated that these are also trending toward equalization. Many of the plots exhibit a cycle that could be seasonal; however continued monitoring over a much longer period will be required before this can be confirmed. Erconeous VWPT readings began in July 1987. No valid VWPT data were gathered between July 1987 and February 1988 because of. system readout damage caused by lightning. Hydraulic head appears to have increased during the period in which the VwPTs were damaged. Since the 1988 data does show equalization or an 


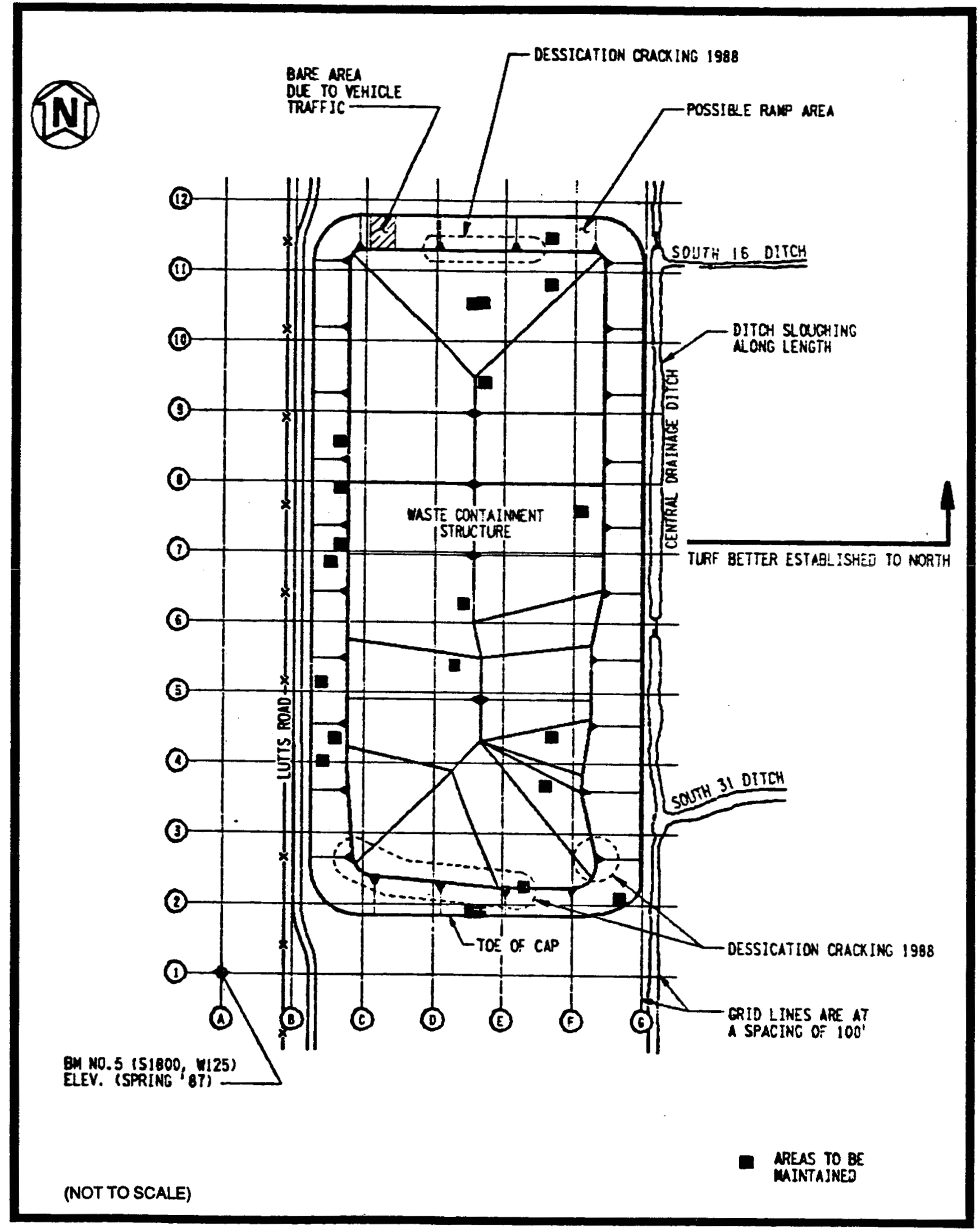

FIGURE 3-4 AREAS REQUIRING MAINTENANCE ACTIONS - WCS 
TABLE 3-3

SUMMARY OF SUBSURFACE MONITORING INSTRUMENTS

1987

\begin{tabular}{|c|c|c|c|c|c|c|c|}
\hline \multirow{2}{*}{$\begin{array}{c}\text { INSTRUMENT } \\
\text { (BOREHOLE) } \\
\text { WUMBER }\end{array}$} & \multicolumn{2}{|c|}{ SITE GRID COORDINATES } & \multirow[b]{2}{*}{$\begin{array}{l}\text { RECORDER } \\
\text { CHANNEL }\end{array}$} & \multicolumn{4}{|c|}{ ELEVATION-FT (MSL) } \\
\hline & SOUTH & EAST & & GROUND & (CAP) & SURFACE & INSTRUMENT* \\
\hline 1 & 885 & 100 & 11 & & 335.2 & & 321.2 \\
\hline 2 & 885 & 220 & 12 & & 341.4 & & 320.7 \\
\hline 3 & 885 & 360 & 13 & & 335.6 & & 320.1 \\
\hline 4 & 1045 & 100 & 14 & & 335.4 & & 321.4 \\
\hline 5 & 1045 & 235 & 15 & & 344.9 & & 320.6 \\
\hline 6 & 1045 & 400 & 16 & & 332.9 & & 320.6 \\
\hline 7 & 1205 & 100 & 17 & & 335.3 & & 320.6 \\
\hline 8 & 1195 & 250 & 18 & & 343.6 & & 319.6 \\
\hline 9 & 1205 & 400 & 19 & & 334.8 & & 322.6 \\
\hline $10 A^{\star *}$ & 1460 & 130 & 10 & & 338.9 & & 327.6 \\
\hline 11 & 1561 & 98 & 1 & & 339.0 & & 323.8 \\
\hline 12 & 1560 & 265 & 2 & & 341.4 & & 329.4 \\
\hline 13 & 1560 & 370 & 3 & & 341.5 & & 329.0 \\
\hline
\end{tabular}

*1987 instrument. elevations are based on as-built conditions.

1986 instrument elevations are based on design conditions.

**Instrument 10 was damaged during construction, Instrument $10 \mathrm{~A}$ was installed as a replacement. 
equalization trend, the increase in hydraulic head is probably due to recalibration and/or reactivation of the VWPTs rather than an actual increase in water level within the wCS. To date, no data have been collected that exhibit any trends indicating weaknesses developing in the clay cap, the cutoff wall/dike, or the gray clay unit.

Data from the PPTs have been converted into hydraulic head and are compared with the corresponding data from the VWPTs in Appendix $B$. Monthly readings of the PPTs began in July 1987. The data from the PPT readings showed no unexpected changes in conditions.

\subsection{ENVIRONMENTAL MONITORING}

Environmental monitoring results at the NFSS are reported in the annual site environmental monitoring report for calendar year 1987 (Ref. 4). This subsection sumarizes the results of 1987 monitoring for radon and external gamma radiation levels, and reports results of groundwater monitoring in the vicinity of the wCS.

\subsubsection{Radon}

Annual average concentrations of radon measured at the NFSS boundary in 1987 ranged from $1.0 \times 10^{-10} \mu \mathrm{Ci} / \mathrm{ml}$ to $8.0 \times 10^{-10} \mu \mathrm{Ci} / \mathrm{ml}$

$(0.17$ to $0.80 \mathrm{pCi} / 1)$. The annual average background radon level was measured at $2.0 \times 10^{-10} \mu \mathrm{Ci} / \mathrm{ml}(0.20 \mathrm{pCi} / 1)$. Although the background radon levels were exceeded, the measured level is not above the $3 \mathrm{pCi} / 1$ guideline per DOE Order 5480.1A (Ref. 5), and is not significant.

\subsubsection{External Gamma Radiation Levels}

Annual average external gamma radiation levels at the NFSS site boundary ranged from background levels to $24 \mathrm{mR} / \mathrm{yr}$ above background. which was measured at $64 \mathrm{mR} / \mathrm{yr}$. These levels are within guidelines of $100 \mathrm{mR} / \mathrm{Yr}$. 


\subsubsection{Groundwater Monitoring}

Prior to 1986, 14 surface water, groundwater, and sediment sampling locations existed on the site at NFSS. Two surface water and sediment sampling locations and two groundwater sampling wells existed off-site. The two off-site sampling wells were deleted from the monitoring program in 1987. Since 1986, 36 additional

groundwater monitoring wells have been installed. Surface water and groundwater monitoring continued as part of the overall site environmental monitoring program. This subsection reports surface water and groundwater monitoring data from those wells adjacent to or in the near vicinity of the wCs. The locations of these wells are shown on Figures 3-5A, 3-5B, and 3-5C. Concentrations of uranium and radium-226 in surface water and groundwater samples from these wells are reported in Tables 3-4 through 3-7.

Tables 3-4 through 3-7 report only 1987 and the first two quarters of 1988 data: however, the overall groundwater monitoring results from 1983 to 1988 have been similar (Ref. 4). As reported earlier, the groundwater monitoring program was greatly expanded in 1987 by the addition of 36 monitoring wells (see Figure 3-5A) to the monitoring program. The established data record and expanded monitoring program provide the information necessary for guickly detecting any increases in radionuclide concentrations in surface water and groundwater.

In general, the data reported in Tables 3-4 through 3-7 show a small seasonal fluctuation in the values; however, during the monitoring period no significant releases were detected. All of the values presented in the data tables are near background levels, with the exception of the surface water samples that were collected in April 1987 during a planned discharge of treated water, and the samples collected from Wells A-42 and A-52. All of the samples are well below the DOE guidelines, with the maximum concentration of uranium in Well A-42 being approximately 16 percent of the DOE guidelines. special tests are being developed to identify the source of the high concentrations. The special tests are expected to be conducted during the fourth quarter of 1988 . 


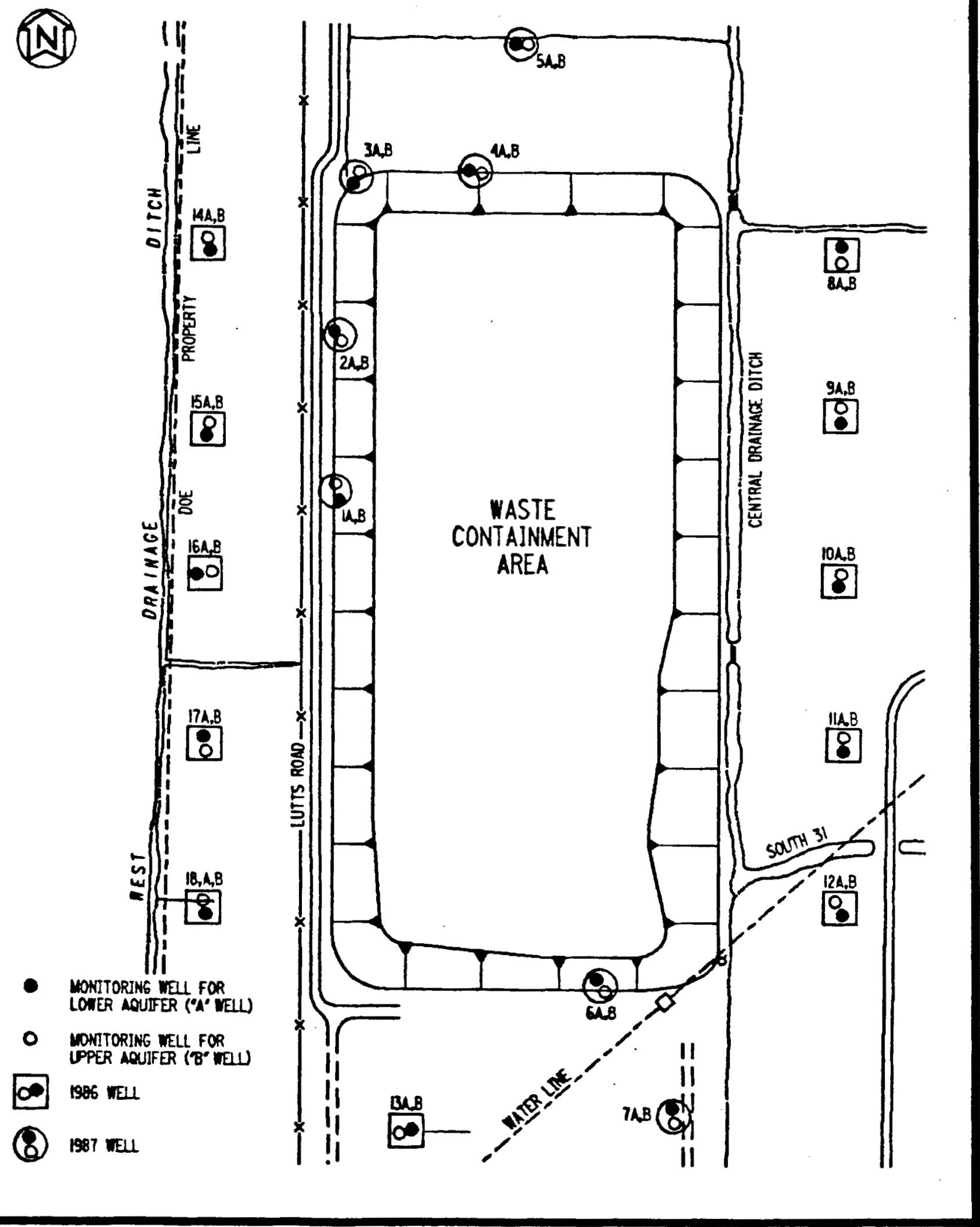

FIGURE 3-5A LOCATION OF NFSS GROUNDWATER MONITORING WELLS IN THE VICINITY OF THE WASTE CONTAINMENT STRUCTURE 


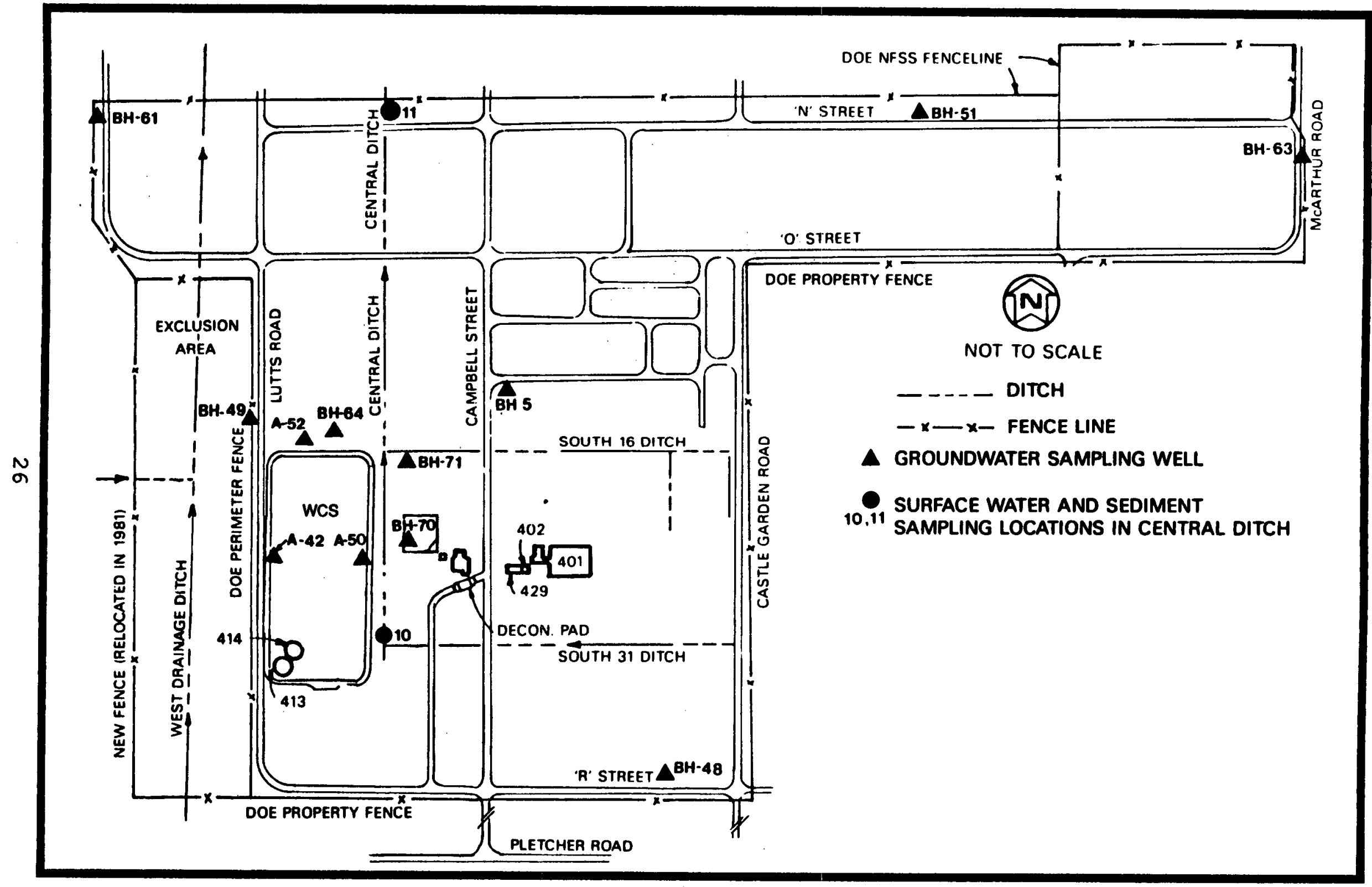

FIGURE 3-5B SURFACE WATER, GROUNDWATER, AND SEDIMENT SAMPLING LOCATIONS AT THE NFSS 


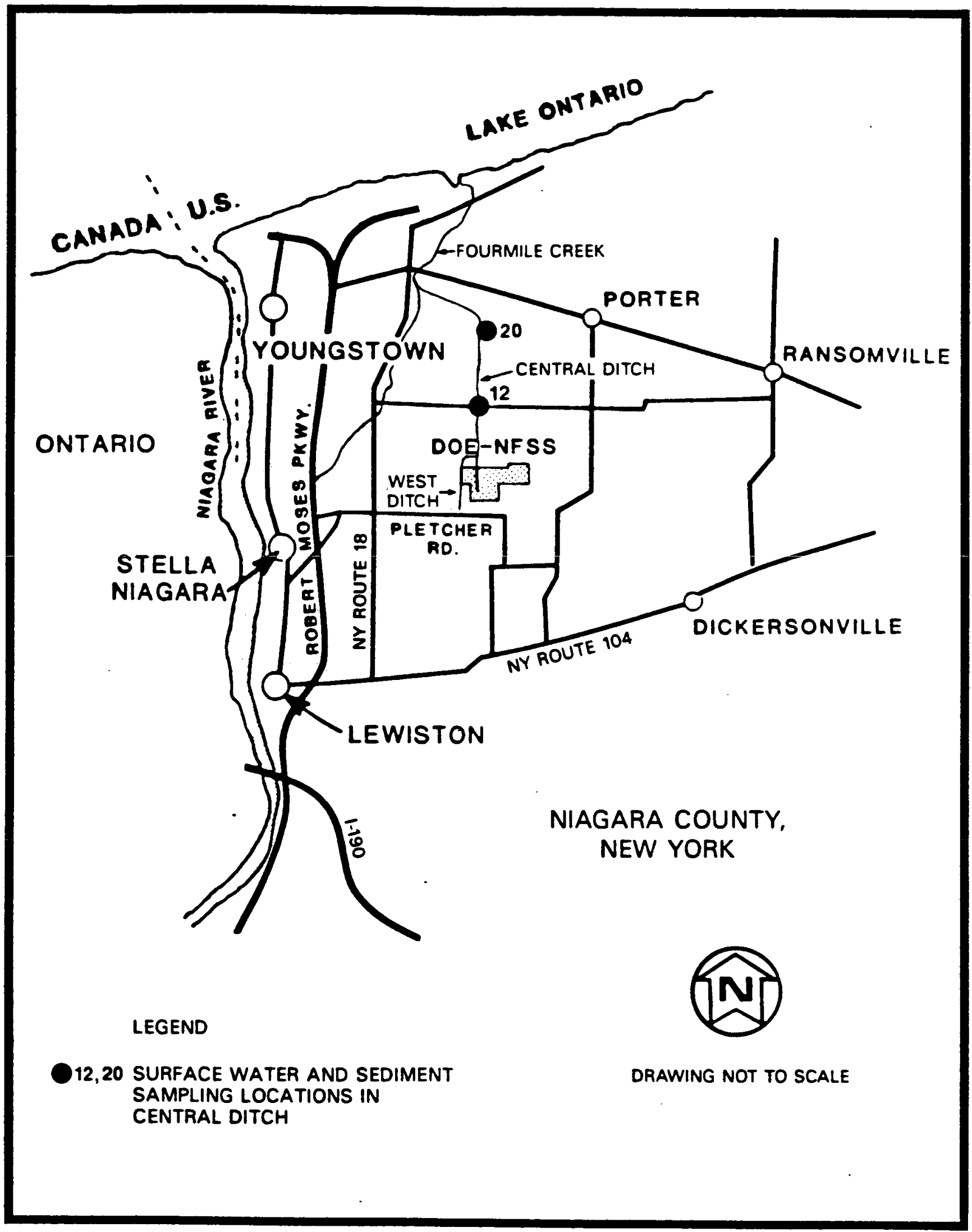

FIGURE 3-5C SURFACE WATER, AND SEDIMENT SAMPLING LOCATIONS IN THE VICINITY OF THE NFSS 
TABLE 3-4

CONCENTRATIONS OF URANIUM IN NFSS WATER SAMPLES -

DECEMBER 1986 TO APRIL 1988

\begin{tabular}{|c|c|c|c|c|c|c|}
\hline \multirow{2}{*}{$\begin{array}{l}\text { Sampling } \\
\text { Locationa }\end{array}$} & \multicolumn{6}{|c|}{ Concentration $\left(10^{-9} \mu \mathrm{Ci} / \mathrm{ml}\right)^{\mathrm{b}, \mathrm{d}}$} \\
\hline & $12 / 86$ & $4 / 87^{C} \quad 7 / 87$ & $10 / 87$ & $2 / 88$ & $4 / 88$ & $\overline{\mathrm{Avg}}$ \\
\hline
\end{tabular}

Surface Water

On-site

10

11

$<3 \quad 10$

$<3$

10

Frozen 7

7

Frozen 8

13

Off-site

$\begin{array}{lrrrrrrr}12 & 5 & 7 & <3 & <3 & \text { Frozen } & <3 & 4 \\ 20 & \text { Dry } & 12 & <3 & 5 & \text { Frozen } & <3 & 6\end{array}$

Groundwater

On-Site

BH-5

BH- 48

BH- 61

A- 42 e

A-50

BH-49

BH- 51

BH -63

A-52

BH- 64

BH-70

BH- 71

$\begin{array}{rr}<3 & <3 \\ 5 & 5 \\ <3 & <3 \\ 73 & 73 \\ 5 & 4 \\ <3 & <3 \\ 7 & <3 \\ <3 & 4 \\ 19 & 17 \\ 11 & 12 \\ <3 & <3 \\ <3 & <3\end{array}$

$\begin{array}{rr}<3 & <3 \\ <3 & 5 \\ <3 & <3 \\ 93 & 73 \\ 5 & 4 \\ <3 & <3 \\ 9 & 6 \\ <3 & <3 \\ 19 & 19 \\ 14 & 12 \\ 5 & <3 \\ <3 & 4\end{array}$

$<3$
$<3$
$<3$
60
$<3$
$<3$
5
$<3$
21
9
$<3$
$<3$

$\begin{array}{rr}<3 & 3 \\ <3 & 4 \\ <3 & 3 \\ 63 & 73 \\ <3 & 4 \\ <3 & 3 \\ <3 & 6 \\ <3 & 3 \\ 4 & 17 \\ 9 & 11 \\ 5 & 4 \\ <3 & 3\end{array}$

asampling locations are shown in Figures 3-5A, 3-5B, and 3-5C.

bl $\times 10^{-9} \mu \mathrm{Ci} / \mathrm{ml}$ is equivalent to $1 \mathrm{pCi} / 1$.

concentrations were atypically high in April, when sampling of the Central Drainage Ditch coincided with a planned discharge of water from the ditch.

dMaximum allowable limit is $600 \mathrm{pCi} / 1$ per DOE Order $5480.1 \mathrm{~A}$ (Ref. 5).

ecollection of field data to explain above-background uranium concentrations in Well A-42 water samples is planned. 
TABLE 3-5

CONCENTRATIONS OF RADIUM-226 IN NFSS WATER SAMPLES -

DECEMBER 1986 TO APRIL 1988

Sampling

Locationa

$12 / 86$

Conce

$\underset{7 / 87}{\frac{10 / 87}{4 C i}} \frac{\left(10^{-9}\right)^{b, d}}{1 / 88}$

$4 / 88$

$\overline{A v g}$

Surface Water

On-site

10

11

0.1

0.2

0.3

0.2 Frozen

0.3

0.2

6.0

0.6

0.3 Frozen

$1.0 \quad 12.0$

Off-site
12
0.2
0.4
0.5
0.1
Frozen
0.10 .3
20
DIY
0.5
0.2 Frozen
0.10 .3

Groundwater

On-site

$\begin{array}{llllllll}\text { BH-5 } & 0.5 & 0.3 & 0.4 & 0.3 & 0.4 & 0.3 & 0.4 \\ \text { BH-48 } & 0.4 & 0.5 & 0.6 & 0.6 & 0.1 & 0.6 & 0.5 \\ \text { BH-61 } & 0.3 & 0.3 & 0.4 & 0.3 & 0.5 & 0.4 & 0.4 \\ \text { A-42 } & 0.1 & 0.2 & 0.3 & 0.3 & 0.3 & 0.4 & 0.3 \\ \text { A-50 } & 0.3 & 0.1 & 0.4 & 0.2 & 0.2 & 0.2 & 0.2 \\ \text { BH-49 } & 0.1 & 0.1 & 0.1 & 0.3 & 0.1 & 0.3 & 0.2 \\ \text { BH-51 } & 0.4 & 0.2 & 0.4 & 0.2 & 0.1 & 0.5 & 0.3 \\ \text { BH-63 } & 0.2 & 0.4 & 0.3 & 0.1 & 0.4 & 0.3 & 0.3 \\ \text { A-52 } & 0.2 & 0.1 & 0.2 & 0.1 & 0.2 & 0.4 & 0.2 \\ \text { BH-64 } & 0.4 & 0.1 & 0.2 & 0.1 & 0.2 & 0.2 & 0.2 \\ \text { BH-70 } & 0.4 & 0.4 & 0.3 & 0.2 & 0.5 & 0.4 & 0.4 \\ \text { BH-71 } & 0.4 & 0.5 & 0.1 & 0.1 & 0.3 & 0.2 & 0.3\end{array}$

asampling locations are shown in Figures 3-5A, 3-5B, and 3-5C.

bl $\times 10^{-9} \mu \mathrm{Ci} / \mathrm{ml}$ is equivalent to $1 \mathrm{pCi} / 1$.

concentrations were atypically high in April, when sampling of the Central Drainage Ditch coincided with a planned discharge of water from the ditch.

dMaximum allowable limits are $100 \mathrm{pCi} / 1$ per DOE Order $5480.1 \mathrm{~A}$ (Ref. 5). 
TABLE 3-6

CONCENTRATIONS OF URANIUM IN THE NFSS CONTAINMENT MONITORING WELLS - APRIL 1987 TO APRIL $1988^{a}$

\begin{tabular}{|c|c|c|c|c|c|c|}
\hline \multirow{2}{*}{$\begin{array}{l}\text { Sampling } \\
\text { Location }\end{array}$} & \multicolumn{6}{|c|}{ Concentration $\left(10^{-9} \mu \mathrm{Ci} / \mathrm{ml}\right)^{b}$} \\
\hline & $4 / 87$ & $7 / 87$ & $10 / 87$ & $1 / 88$ & $4 / 88$ & Avg \\
\hline $1 A$ & $<3$ & 5 & $<3$ & $<3$ & $<3$ & 3.4 \\
\hline IB & 5 & $<3$ & $<3$ & $<3$ & $<3$ & 3.4 \\
\hline $2 A$ & 5 & 4 & $<3$ & $<3$ & $<3$ & 3.6 \\
\hline $\begin{array}{l}2 \mathrm{~B} \\
3 \mathrm{~A}\end{array}$ & $\underset{5}{\operatorname{Dry}}$ & $\begin{array}{r}7 \\
<3\end{array}$ & $\begin{array}{l}<3 \\
<3\end{array}$ & $\begin{array}{r}5 \\
<3\end{array}$ & $\begin{array}{l}8 \\
4\end{array}$ & $\begin{array}{l}5.8 \\
3.6\end{array}$ \\
\hline $3 B$ & $<3$ & 13 & 13 & 11 & 13 & 8.4 \\
\hline $4 A$ & 5 & $<3$ & $<3$ & $<3$ & $<3$ & 3.4 \\
\hline 4B & $<3$ & 7 & 7 & 5 & 7 & 5.8 \\
\hline $5 A$ & 10 & $<3$ & $<3$ & $<3$ & $<3$ & 4.4 \\
\hline $5 B$ & $<3$ & 15 & 12 & 9 & 10 & 9.8 \\
\hline $6 A$ & 11 & $<3$ & $<3$ & $<3$ & $<3$ & 4.6 \\
\hline $6 B$ & $<3$ & 20 & 15 & 13 & 16 & 13 \\
\hline $7 \mathrm{~A}$ & 7 & $<3$ & $<3$ & 9 & 11 & 6.6 \\
\hline $7 B$ & $<3$ & 11 & $\overline{8}$ & Dry & $<3$ & 6.3 \\
\hline $8 \mathrm{~A}$ & 23 & $<3$ & $<3$ & $<3$ & 4 & 7.2 \\
\hline 8B & 10 & 19 & 9 & 16 & 21 & 15 \\
\hline $9 A$ & $<3$ & 19 & 13 & 4 & $<3$ & 9.8 \\
\hline $9 B$ & $<3$ & $<3$ & $<3$ & 18 & 23 & 10 \\
\hline $10 A$ & $<3$ & 10 & $<3$ & $<3$ & $<3$ & 4.4 \\
\hline $10 B$ & 25 & $<3$ & 4 & 8 & 7 & 9.4 \\
\hline $11 \mathrm{~A}$ & $<3$ & 53 & $<3$ & 26 & 43 & 26 \\
\hline $11 B$ & 15 & $<3$ & 25 & $<3$ & $<3$ & 0.8 \\
\hline $12 A$ & $<3$ & 16 & 13 & 4 & $<3$ & 7.8 \\
\hline $12 B$ & 11 & $<3$ & $<3$ & 14 & 15 & 9.2 \\
\hline $13 A$ & $<3$ & 16 & 15 & 5 & $<3$ & 8.8 \\
\hline $13 \mathrm{~B}$ & 4 & $<3$ & $<3$ & 15 & 21 & 9.2 \\
\hline $14 A$ & $<3$ & 5 & 6 & 4 & $<3$ & 4.2 \\
\hline $14 \mathrm{~B}$ & $<3$ & $<4$ & $<3$ & 8 & 5 & 4.6 \\
\hline $15 A$ & $<3$ & 9 & 7 & 4 & $<3$ & 5.2 \\
\hline 15B & $<3$ & $<3$ & $<3$ & 9 & 5 & 4.6 \\
\hline $16 \mathrm{~A}$ & 5 & 4 & $<3$ & 4 & 4 & 4.0 \\
\hline 26B & $<3$ & 9 & 4 & 8 & $<3$ & 5.4 \\
\hline $17 \mathrm{~A}$ & $<3$ & $<3$ & 4 & 4 & $<3$ & 3.4 \\
\hline 17B & $<3$ & 8 & 9 & 7 & 7 & 6.8 \\
\hline $18 \mathrm{~A}$ & $<3$ & 22 & $<3$ & $<3$ & $<3$ & 6.8 \\
\hline $18 \mathrm{~B}$ & $<3$ & $<3$ & $<3$ & $<3$ & 21 & 6.6 \\
\hline
\end{tabular}

asince these wells were incorporated into the monitoring program in April 1987, no data were obtained for the first quarter.

bMaximum allowable limit is $600 \mathrm{pCi} / 1$ per DOE Order 5480.1A (Ref. 5) 
TABLE 3-7

CONCENTRATIONS OF RADIUM-226 IN THE NFSS CONTAINMENT MONITORING WELLS - APRIL 1987 TO APRIL $1988^{\mathrm{a}}$

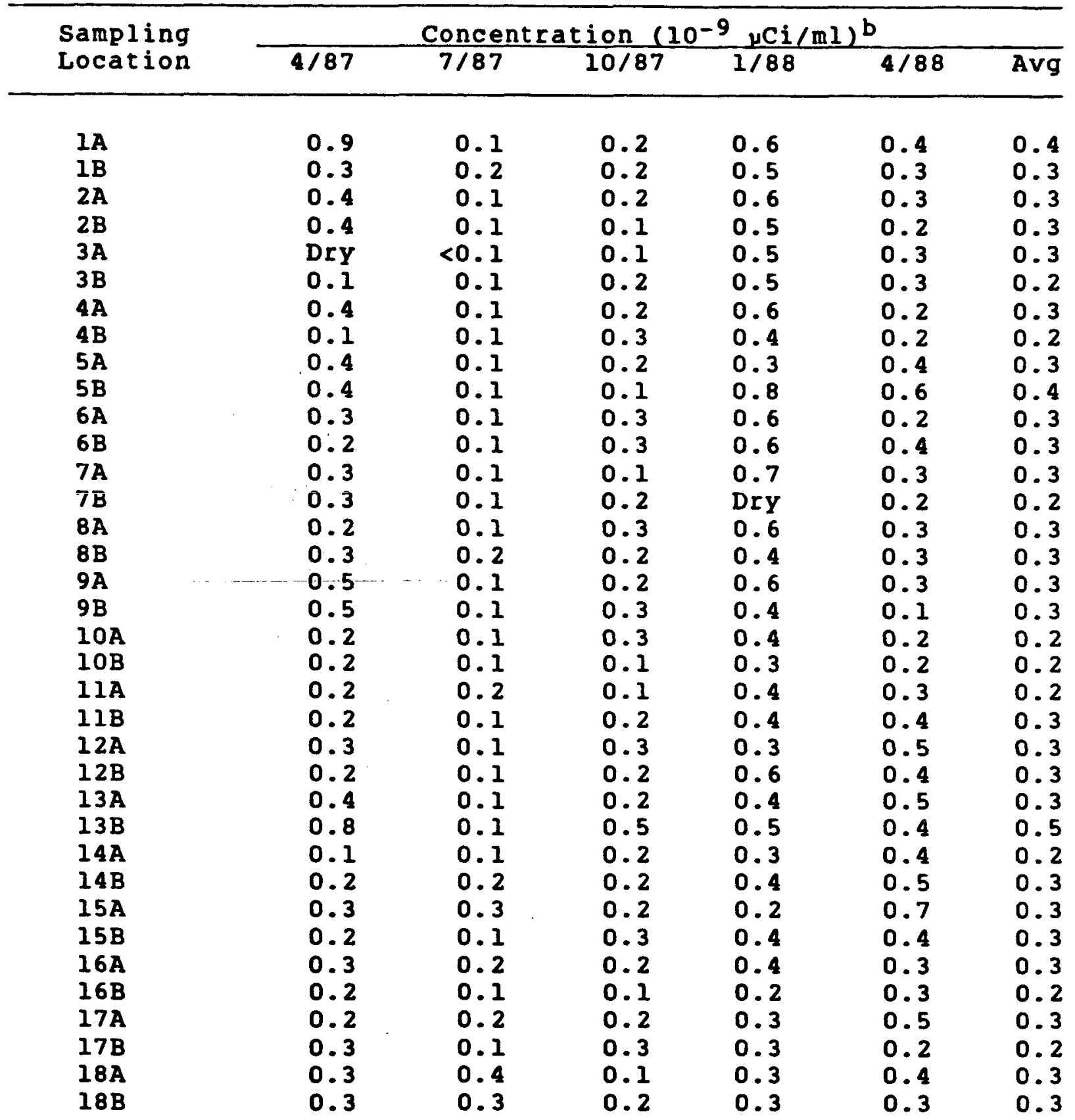

asince these wells were incorporated into the monitoring program in April 1987. no data were obtained for the first quarter.

bMaximum allowable limit is $100 \mathrm{pCi} / 1$ per DOE Order $5480.1 \mathrm{~A}$ (Ref. 5). 


\subsection{COMPARISON WITH PREVIOUS DATA}

The surface conditions at the wcs have improved greatly since performance monitoring began in November 1986. Turf conditions are generally good over the entire wCs. There are bare areas, but these are significantly fewer and smaller than observed in any previous year. There is a bare area on the northwest surface of the wCS where the vehicle that repositions the irrigation guncart has been driven up and down the cap. Drainage has been improved along Lutts Road and at either end of the wCs. There is still minor ponding around the wCS, but this is insignificant when compared to that observed in the initial walkovers. Access conditions leading to the monitoring wells have been improved.

Data from the 1987 Environmental Monitoring Report show there has been no change in the quality of the water collected from the groundwater wells surcounding the wCS, with the exception of well A-42. Special tests are currently being developed to investigate the concentrations found in well A-42. The report also shows that the NFSS is in compliance with the DOE radiation protection standard regarding radon levels, external gamma radiation levels, and calculation of potential dose to the public (Ref. 4).

A water level equalization trend was predicted within the WCs. This equalization trend has continued as predicted. The grass covering the wCS is maturing and appears to be limiting any erosion. The desiccation cracking in the topsoil first observed in 1987 worsened in 1988 due to the record drought. The cracking closed substantially after rains, and no erosion patterns have been observed. 


\subsection{ACTIONS REQUIRED}

In the 1986 performance monitoring report, there were four actions noted. There were also actions arising from the May and October 1987 and May 1988 walkovers. Those actions which have not been completed are noted below:

1. Repair the Central Ditch. A subcontract has been issued for this work and it should be completed in 1988 .

2. Continue observation of the polygonal desiccation cracking condition. If the condition does not improve. actions will be taken to remedy the situation.

3. Grout the penetrations leading into and out of the geotechnical instrumentation manhole.

4. Continue turf maintenance as required. 


\section{REFERENCES}

1. Bechtel National. Inc. Design Report for the Interim Waste Containment Facility at the Niagara Falls storage site. DOE/OR/20722-21, Oak Ridge, TN, May 1986 .

2. Bechtel National. Inc. Closure/Post-Closure Plan for the Interim Waste Containment Facility at the Niagara Falls storage Site, DOE/OR/20722-85, Oak Ridge, TN, May 1986.

3. Bechtel National. Inc. Performance Monitoring Report for the Niagara Falls storage site Waste Containment structure for Calendar Year 1986, DOE/OR/20722-159, Oak Ridge, TN, JulY 1987.

4. Bechtel National. Inc. Niagara Falls storage Site Environmental Monitoring Report, Calendar Year 1987. DOE/OR/20722-150. Oak Ridge, TN, March 1988.

5. U.S. Department of Energy. DOE Order 5480.1A. "Environmental Protection, Safety, and Health Protection Program for DOE Operations," Washington, D.C., August 31, 1981. 


\section{APPENDIX A}

SUMMARY OF VIBRATING WIRE PRESSURE TRANSDUCER DATA FOR CALENDAR YEAR 1987

AND JANUARY-JUNE 1988 


\section{VWPT DATA FOR NFSS}

\section{FIRST HALF - 1987}

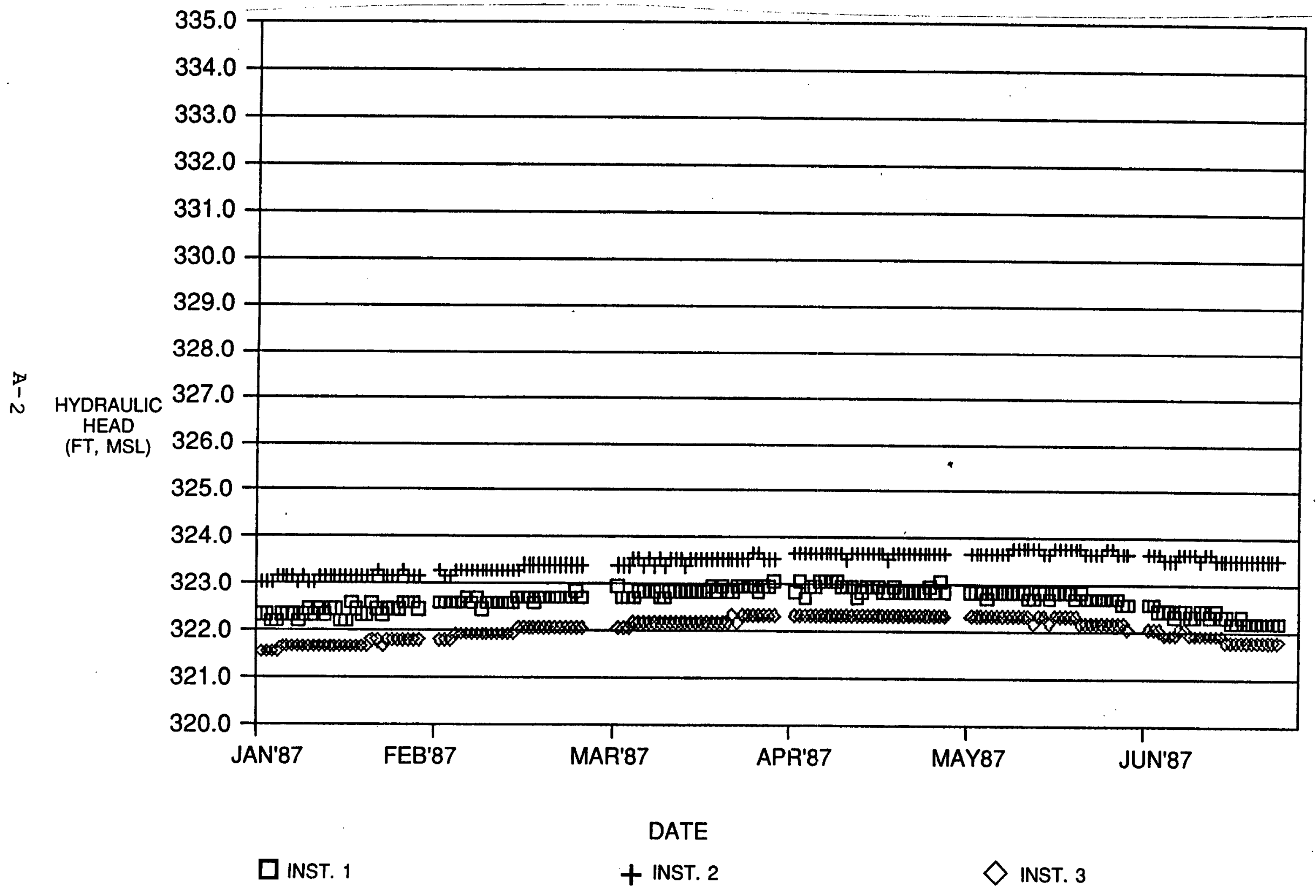




\section{VWPT DATA FOR NFSS}

\section{FIRST HALF - 1987}

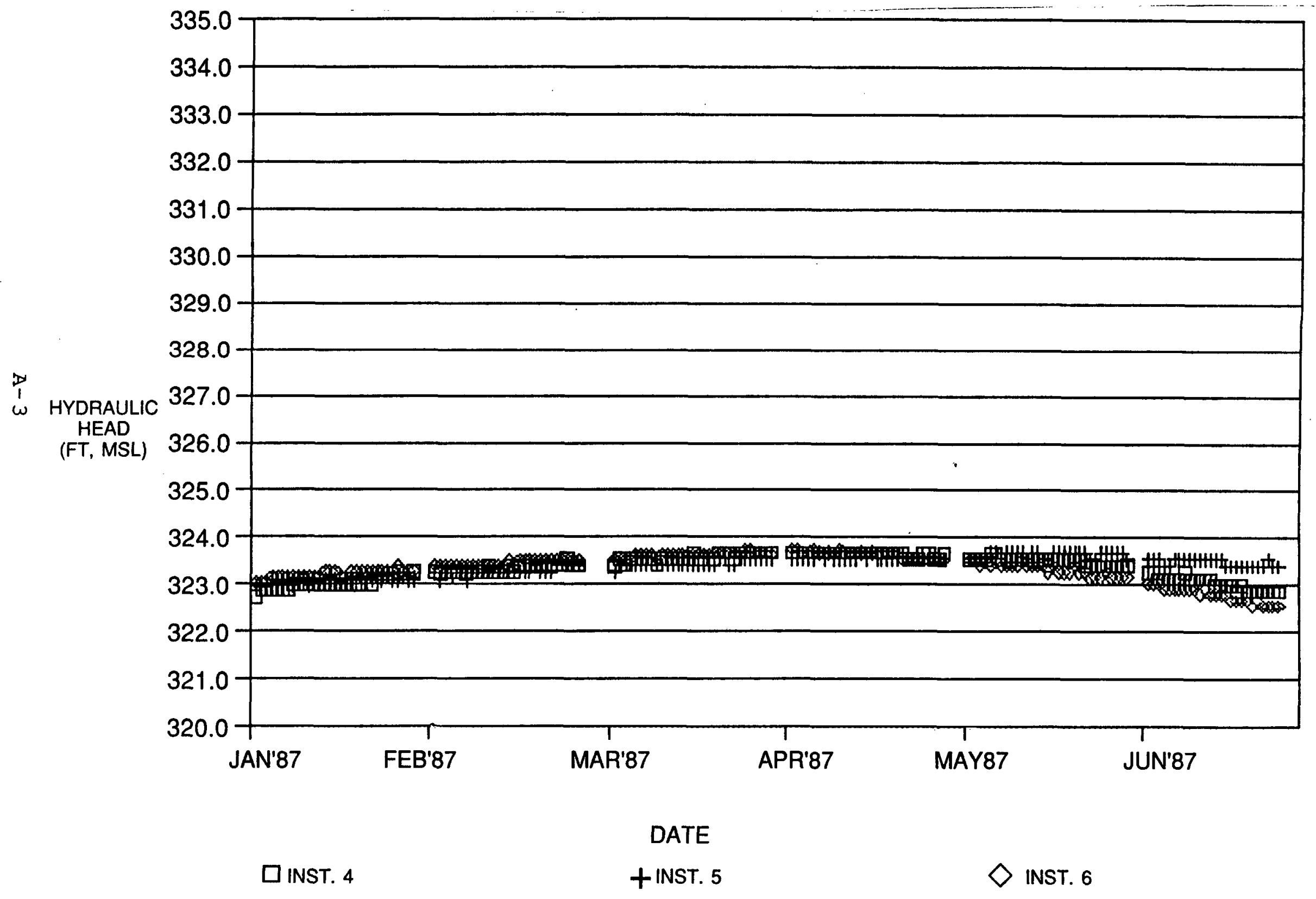




\section{VWPT DATA FOR NFSS}

\section{FIRST HALF - 1987}

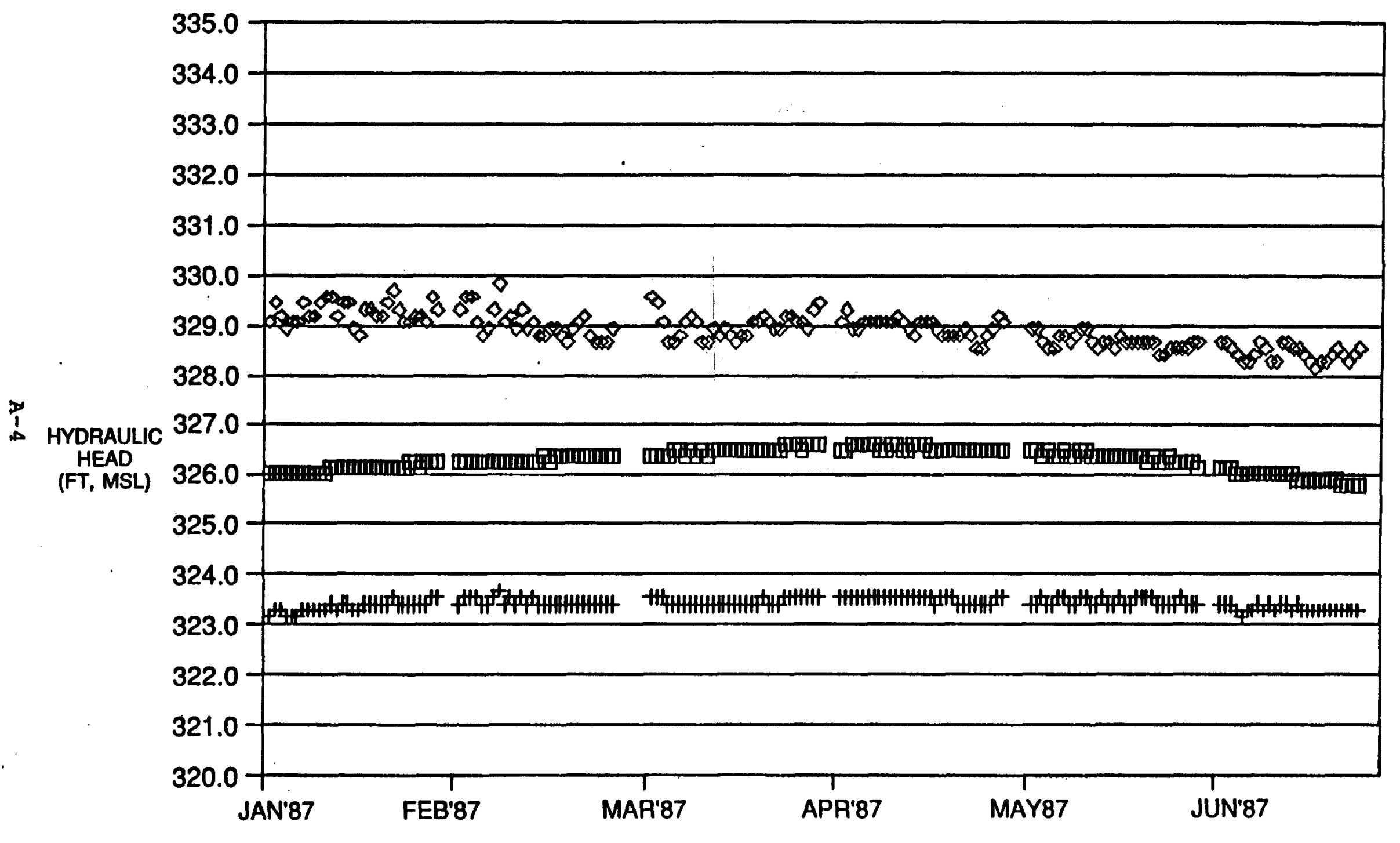

DATE

$\square$ INST. 7

+ INST. 8

$\diamond$ INST. 9 


\section{VWPT DATA FOR NFSS}

\section{FIRST HALF - 1987}

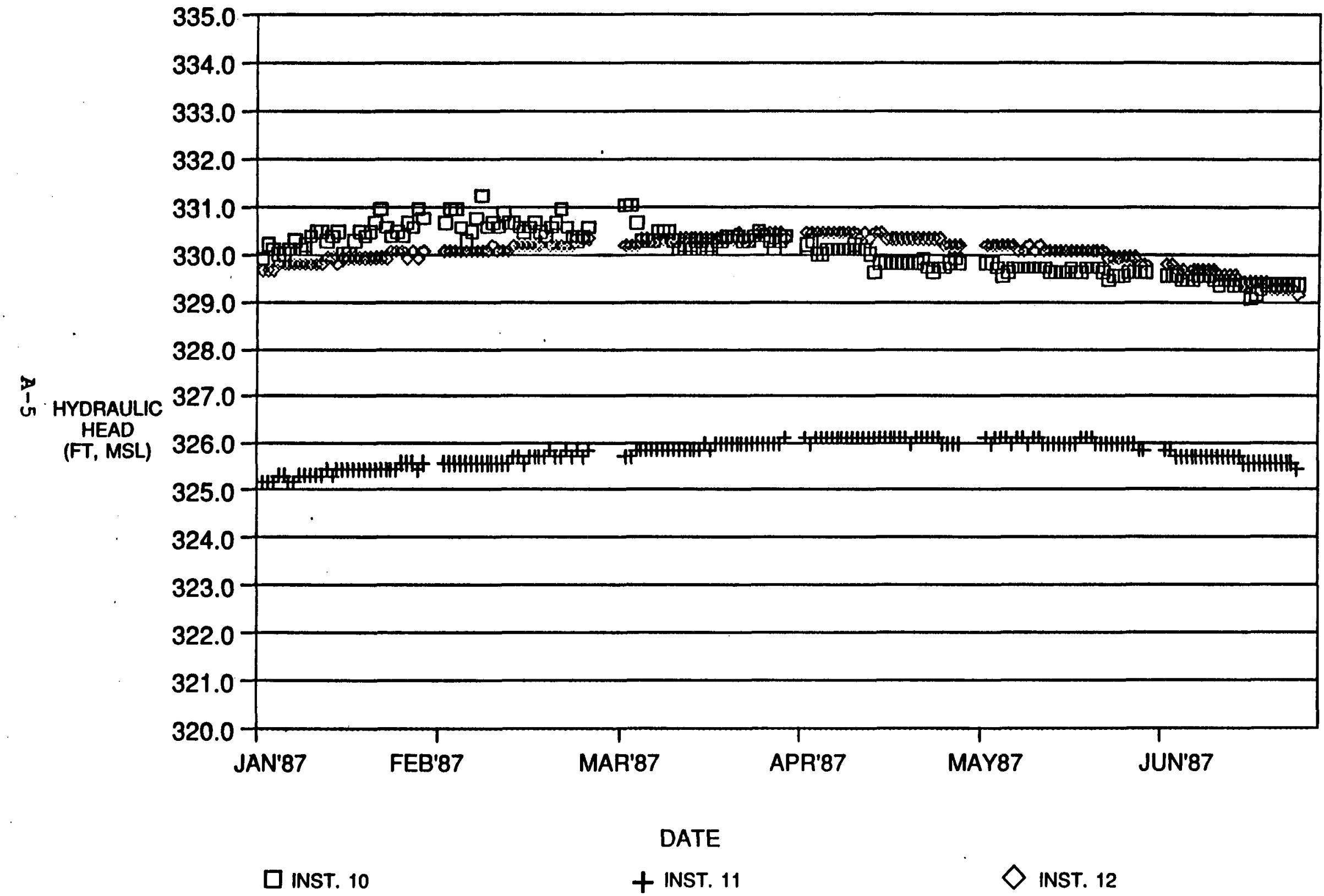




\section{VWPT DATA FOR NFSS}

\section{FIRST HALF - 1987}

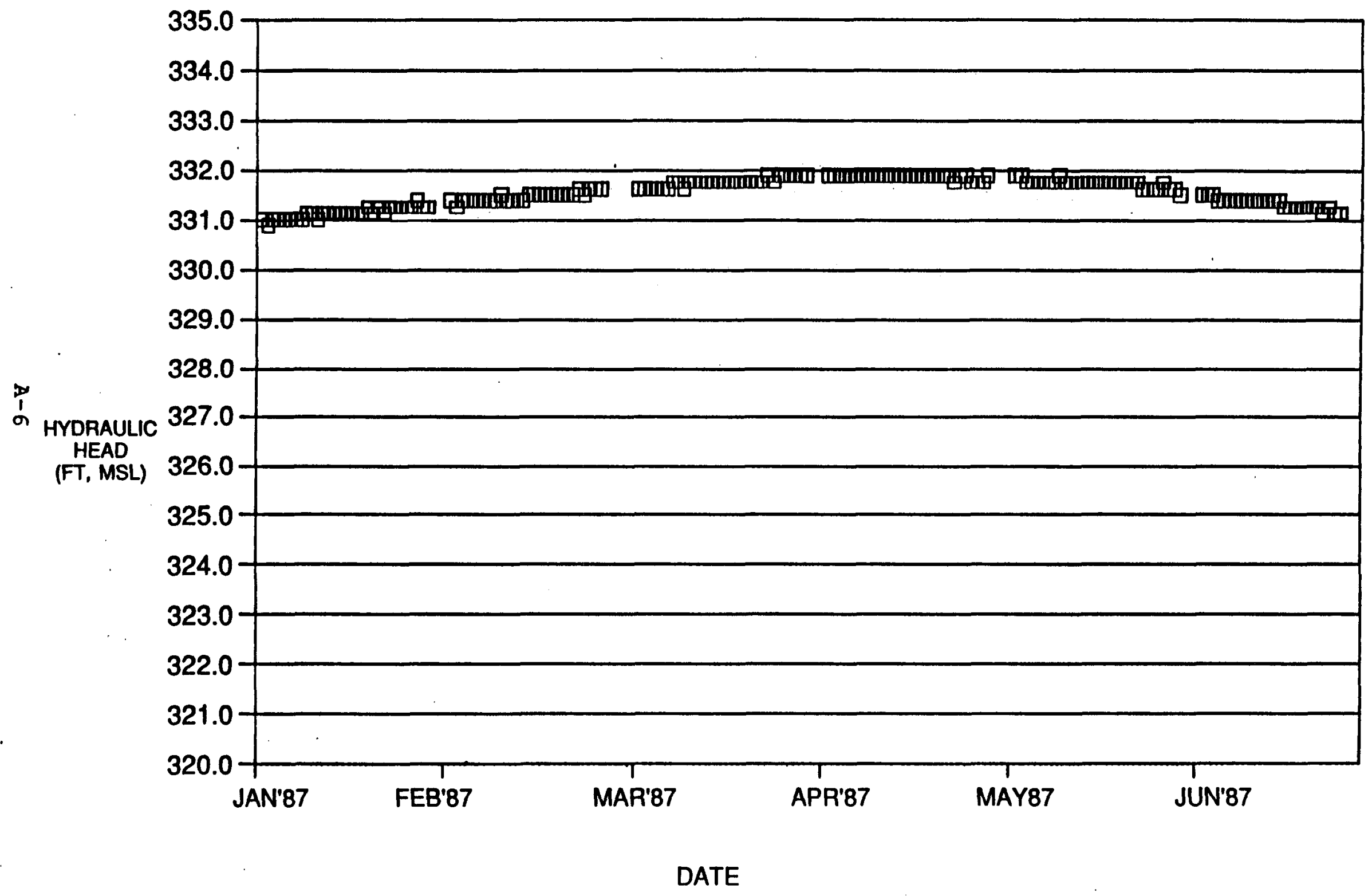

$\square$ INST. 13 


\section{VWPT DATA FOR NFSS FIRST HALF - 1988}

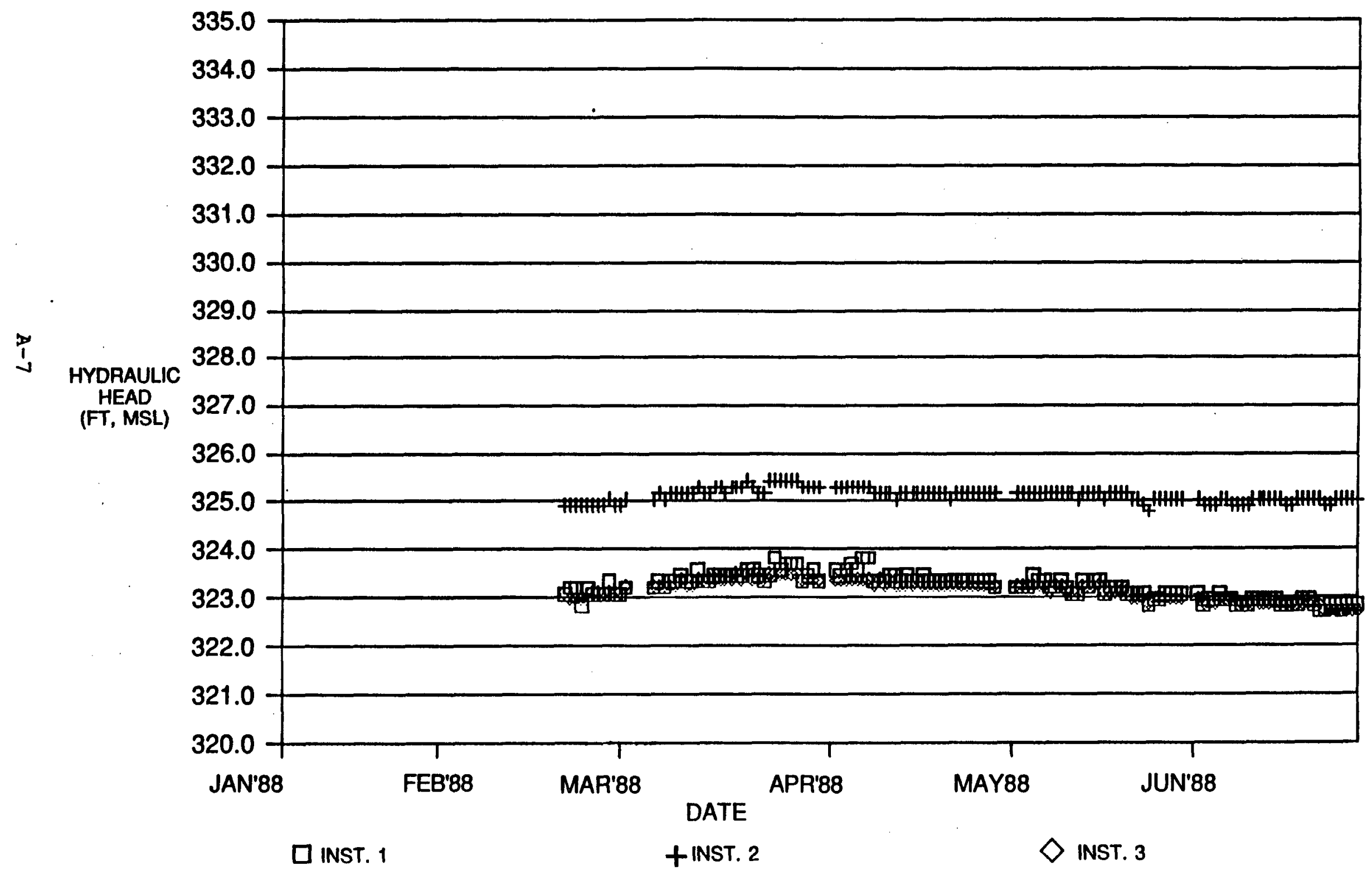




\section{VWPT DATA FOR NFSS}

FIRST HALF - 1988

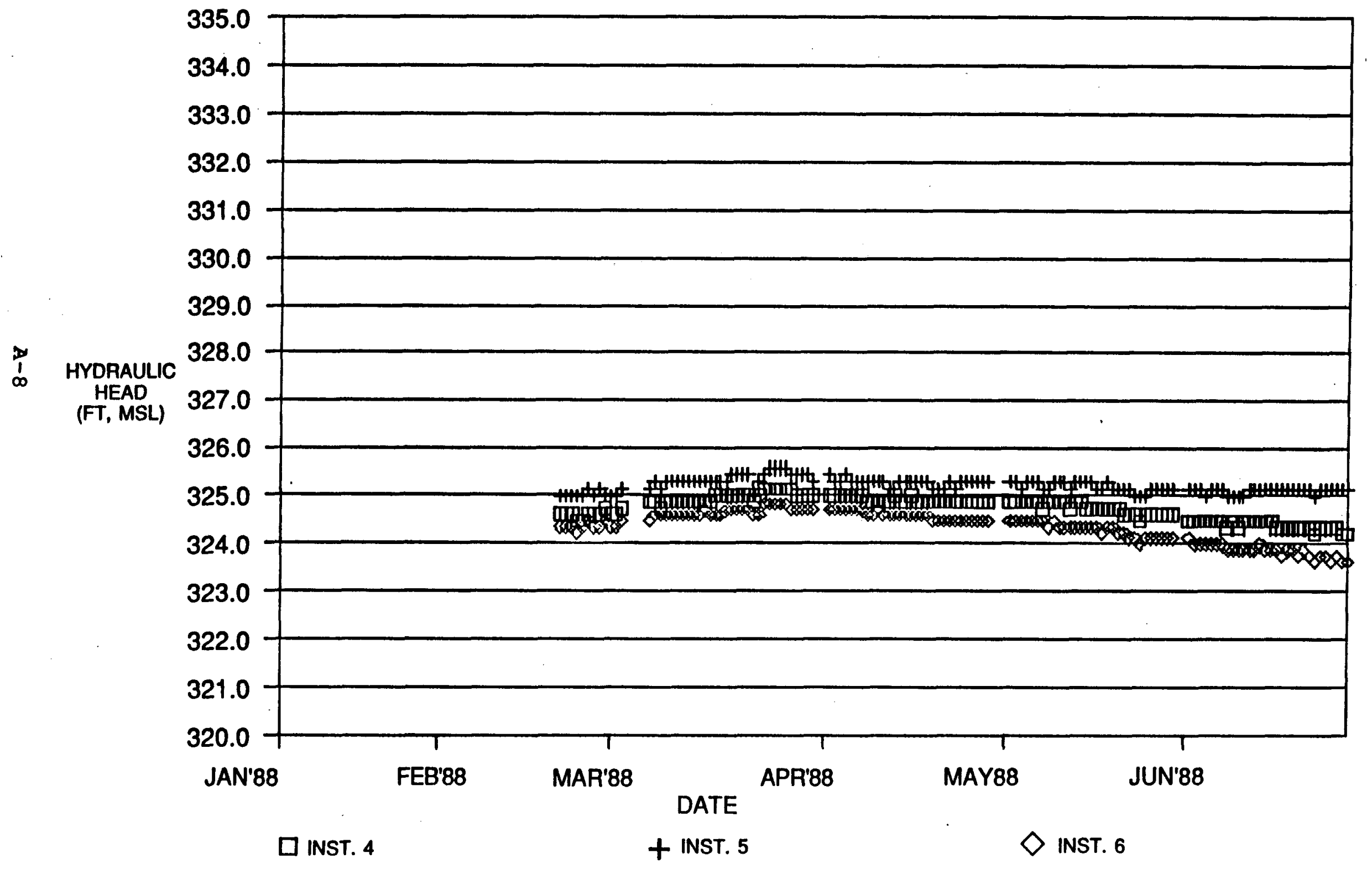




\section{VWPT DATA FOR NFSS FIRST HALF - 1988}

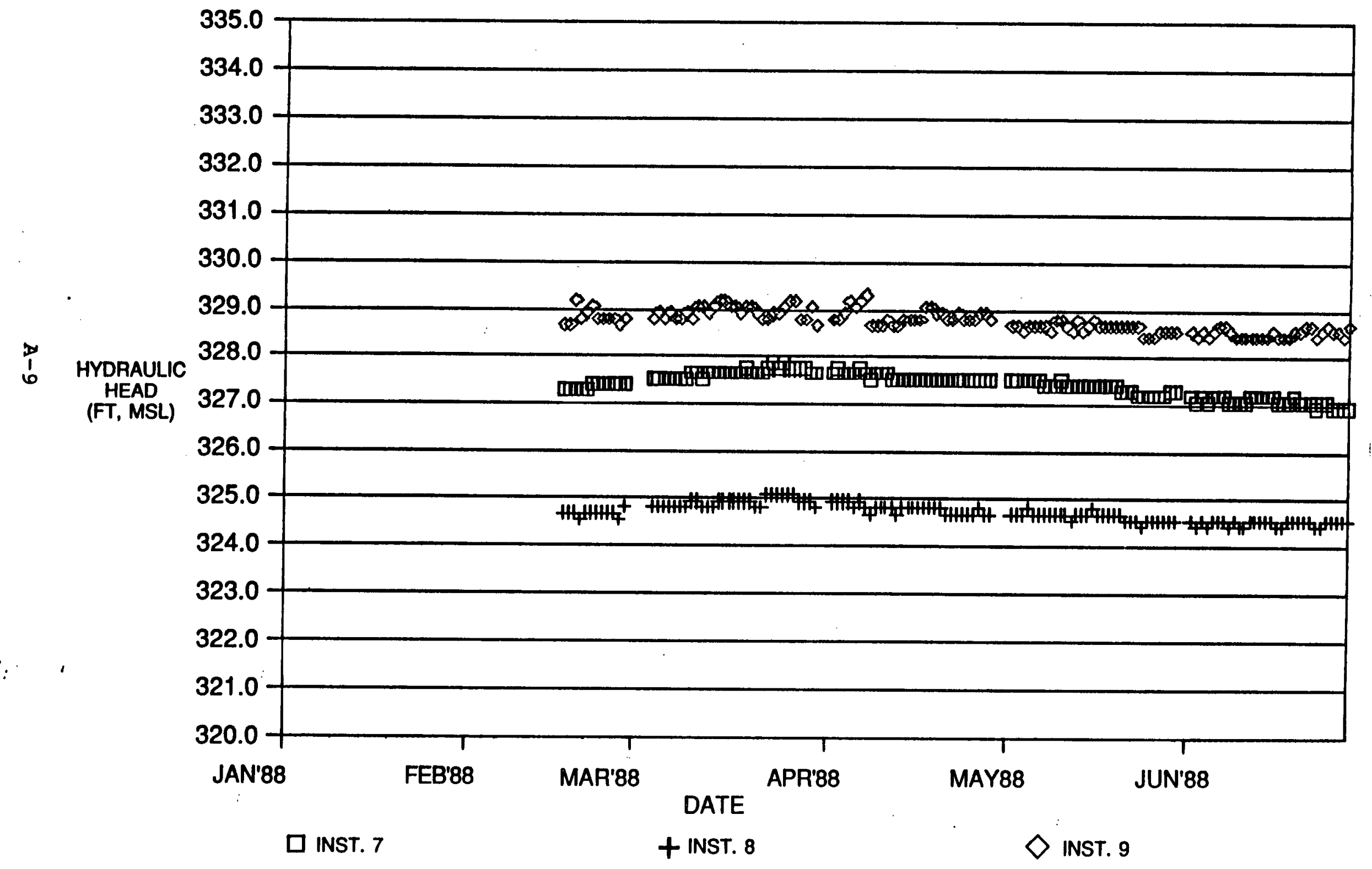




\section{VWPT DATA FOR NFSS}

\section{FIRST HALF - 1988}

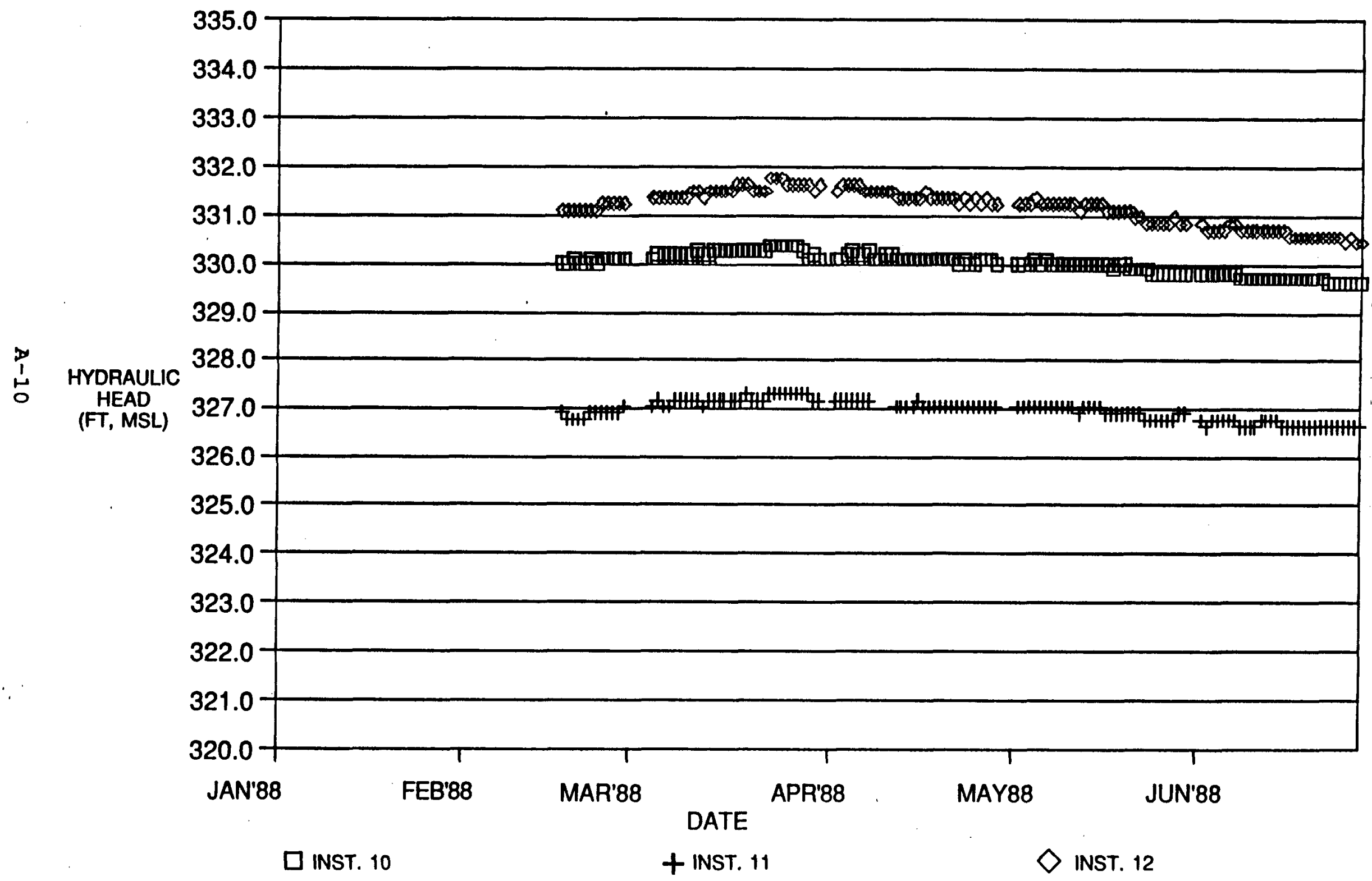




\section{VWPT DATA FOR NFSS \\ FIRST HALF - 1988}

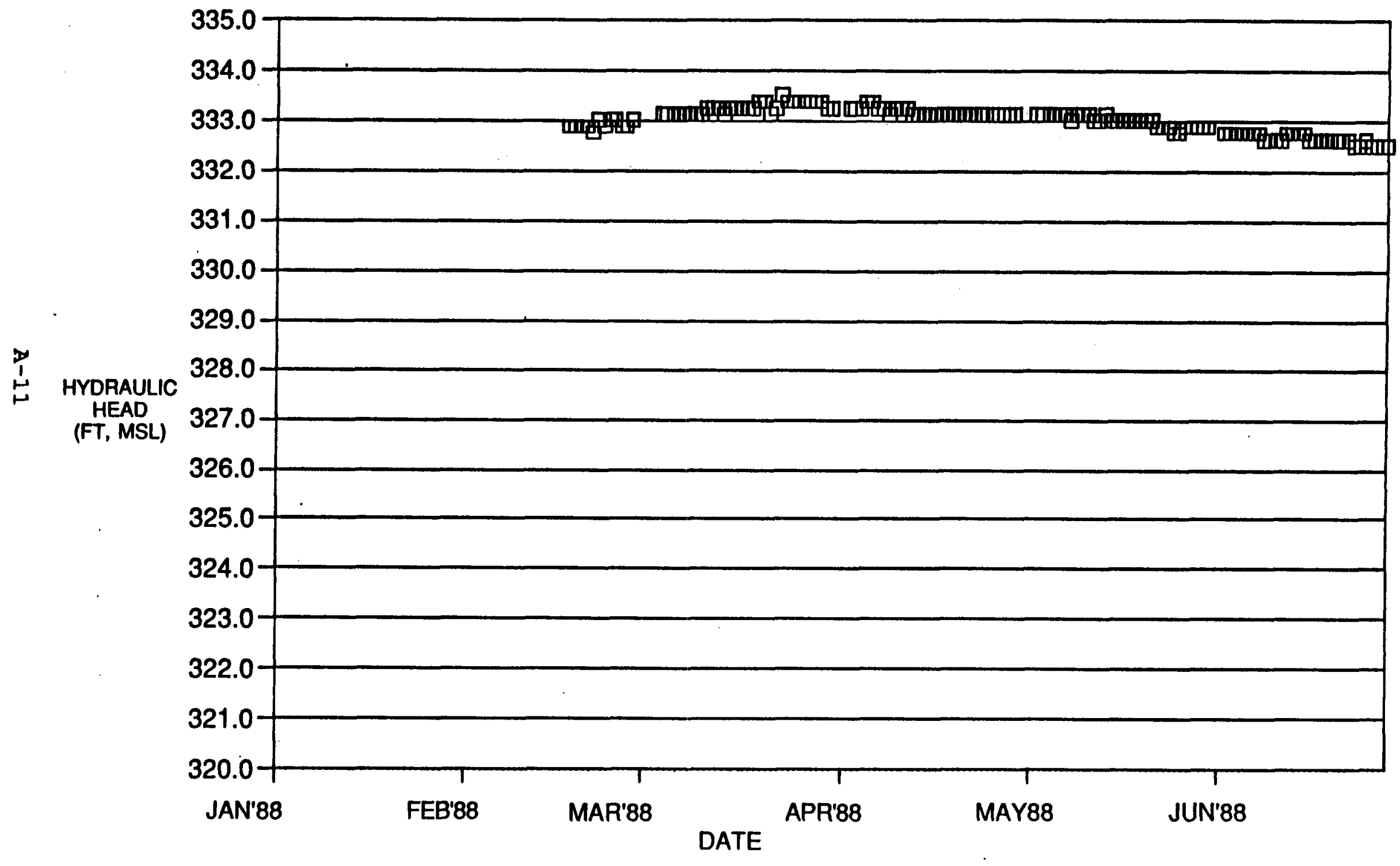

DINST. 13 


\section{APPENDIX B}

COMPARISON OF VIBRATING WIRE PRESSURE TRANSDUCER DATA

TO PNEUMATIC PRESSURE TRANSDUCER DATA -

JULY 1987 TO JUNE 1988 
TABLE B-1

COMPARISON OF VWPT DATA TO PPT DATA -

JULY 1987 to JUNE 1988

\begin{tabular}{|c|c|c|c|c|c|c|}
\hline \multirow[b]{3}{*}{ Date } & \multicolumn{6}{|c|}{ Instrument Locationa } \\
\hline & \multicolumn{2}{|c|}{1} & \multicolumn{2}{|c|}{9} & \multicolumn{2}{|c|}{13} \\
\hline & PPT & VWPT & PPT & VWPT & PPT & VWPT \\
\hline $3 / 19 / 87^{b}$ & 1.84 & 1.26 & 0.92 & 5.96 & 0.81 & 2.27 \\
\hline $7 / 16 / 87^{c}$ & 2.54 & 93.18 & 1.38 & 108.46 & 1.61 & 99.05 \\
\hline $8 / 3 / 87$ & 2.54 & 1.14 & 1.38 & 13.54 & 1.61 & 7.24 \\
\hline $9 / 3 / 87$ & 2.54 & 0.39 & 1.15 & 12.89 & 1.61 & 6.49 \\
\hline $10 / 5 / 87^{d}$ & 2.31 & & 1.38 & & 1.61 & \\
\hline $11 / 3 / 87$ & 2.31 & d & 1.15 & d & 1.85 & d \\
\hline $12 / 8 / 87$ & 2.31 & d & 1.15 & d & 1.85 & $d$ \\
\hline $1 / 5 / 88$ & 2.31 & d & 1.15 & d & 1.85 & d \\
\hline $2 / 10 / 88^{e}$ & 2.31 & 2.38 & 1.15 & 7.63 & 1.61 & 4.25 \\
\hline $3 / 2 / 88$ & 2.31 & 1.64 & 1.15 & 5.83 & 1.61 & 3.63 \\
\hline $4 / 4 / 88$ & 2.31 & 2.01 & 1.15 & 6.09 & 1.61 & 3.88 \\
\hline $5 / 3 / 88$ & 2.31 & 1.51 & 1.15 & 5.44 & 1.61 & 3.63 \\
\hline $6 / 2 / 88$ & 2.31 & 1.14 & 1.15 & 5.95 & 1.61 & 3.26 \\
\hline
\end{tabular}

apPTs and VWPTs are placed at the same elevation. Instrument readings are converted to hydraulic head above the instrument.

b The PPTs were read in March 1987 to establish a correlation with the VWPT data.

CJuly 1987 readings of the VWPTs showed a large increase in the hydraulic head. Comparison with the PPT data shows that the increase was not valid.

dThe damaged VWPT system was repaired during the period of October 1987 through December 1987. No readings of the VWPTs were taken during this time.

Eebruary 1988 readings of the VWPTs showed a return to valid information. Although variation exists between the PPT and VWPT data (PPTs are not as sensitive and are more susceptible to outside influences) the differences are within a reasonable range. 